Article

\title{
Syntheses, Structures, and Magnetic Properties of a Series of Heterotri-, Tetra- and Pentanuclear Ln ${ }^{\text {III_Co }}{ }^{\text {II }}$ Compounds
}

\author{
Yun Xu ${ }^{1,2}$, Feng Luo ${ }^{1}$ and Ji-Min Zheng ${ }^{1, *}$ \\ 1 Department of Chemistry, Nankai University, Tianjin 300071, China; xuyun88@163.com (Y.X.); \\ ecitluofeng@163.com (F.L.) \\ 2 College of Chemistry and Materials Science, HuaiBei Normal University, Huaibei 235000, China \\ * Correspondence: jiminzheng@nankai.edu.cn; Tel.: +86-022-2350-1942
}

Received: 5 December 2018; Accepted: 8 January 2019; Published: 23 January 2019

\begin{abstract}
Three types of $\mathrm{Ln}(\mathrm{III})-\mathrm{Co}(\mathrm{II})$ heterometallic compounds, $\mathrm{LnCo}_{2}(\mathrm{~L} 1)_{7}(\mathrm{bipy})_{2}(\mathrm{Ln}=\mathrm{Pr}-\mathbf{1}, \mathrm{Eu}-\mathbf{2}$, Sm-3, Gd-4, Tb-5, Dy-6) (L1 = 4-chlorobenzoate, bipy = 2,2'-bipyridine), $\mathrm{Ln}_{2} \mathrm{Co}_{2}\left(\mathrm{~L}_{2}\right)_{10}(\text { bipy })_{2}(\mathrm{Ln}=$ Sm-7, Gd-8, Tb-9, Dy-10, Ho-11, Er-12, Yb-13), (L2 = 2,4-dichlorobenzoate, bipy = 2,2'-bipyridine, phen $=1,10$-phenanthroline), and $\mathrm{Ln}_{2} \mathrm{Co}_{3}(\mathrm{~L} 1)_{12}(\text { bipy })_{2}(\mathrm{Ln}=\mathrm{Ho}-14, \mathrm{Er}-15, \mathrm{Yb}-16)$, were synthesized under hydrothermal conditions and characterized by single crystal X-ray diffraction, IR spectroscopy and magnetic measurements. Structural analyses revealed that 14-16 take on a unique linear pentanuclear structural motif. Interestingly, the Ho-containing compound 14 exhibits magnetic relaxation behavior.
\end{abstract}

Keywords: heterometallic; pentanuclear; magnetic properties

\section{Introduction}

Heterometallic compounds containing both d-block transition and f-block lanthanide metal ions have been intensively investigated due to their impressive structural diversity and their exploitable applications in magnetism, luminescent materials and molecular adsorption [1-6]. Because of the the different nature between lanthanide and transition metal ions, the synthesis of a compound containing both of them is difficult compared with the synthesis of a compound containing only one of them. With respect to lanthanide ions, they have a high affinity for binding to hard donors like the $\mathrm{O}$ atom. While most transition metal ions prefer to coordinate to soft donors like the $\mathrm{N}$ atom, many strategies are used for synthesizing compounds containing both lanthanide and transition metal ions, for example, selecting proper multidentate ligands containing both $\mathrm{N}$ - and O-donor atoms, such as pyridine-2,5-dicarboxylic acid, pyridine-2,6-dicarboxylic acid, nicotinic acid, isonicotinic acid and iminodiacetate ligand [7-10]. The use of polycarboxylate and bipyridyl ligands has also proved to be a constructive way to synthesis the $3 \mathrm{~d}-\mathbf{4 f}$ heterometallic compounds [11]. The magnetic property of the $3 \mathrm{~d}-\mathbf{4 f}$ heterometallic compound is also a challenge-because the orbital contributions of most $\mathrm{f}$ electron pairs and the influence of the crystal field effects have to be considered, the analyses of magnetic interactions among $\operatorname{Ln}(\mathrm{III})$ and transition metal ions become very difficult [12-14]. As the ground state of the $\mathrm{Gd}(\mathrm{III})$ ion is ${ }^{8} \mathrm{~S}_{7 / 2}$, the spin-orbit coupling effect is absent, and the influence of the ligand field can be neglected. As a consequence, most studies on $\mathbf{3 d}-\mathbf{4 f}$ structures have involved Gd(III)-M(II) or Gd(III)-M(III) systems [15-19], with examples of the Ln(III)-Co(II) system being much less documented [20].

Inspired by the above mentioned information, we successfully synthesized three series of trinuclear, tetranuclear and pentanuclear $\mathrm{Ln}(\mathrm{III})-\mathrm{Co}(\mathrm{II})$ ions under hydrothermal conditions by selecting 4-chlorobenzoic acid/2,4-dichlorobenzoic acid (L1/L2), bipy as ligands. 


\section{Experimental Section}

\subsection{Materials and Physical Measurements}

All reagents and solvents used for synthesis and analysis are commercially available and were used as received. IR spectra were taken on a Perkin-Elmer spectrum. One FT-IR spectrometer (Thermo Fisher Scientific, Waltham, MA, USA) was used in the $4000-400 \mathrm{~cm}^{-1}$ region with $\mathrm{KBr}$ pellets. Elemental analyses for C, $\mathrm{H}$ and $\mathrm{N}$ were carried out on a Model 2400II, Perkin-Elmer elemental analyzer (Perkin Elmer, Akron, OH, USA). The magnetic susceptibility measurements of the polycrystalline samples were measured over the temperature range of 2-300 K with a Quantum Design MPMSXL7 SQUID magnetometer (Quantum Design, San Diego, CA, USA) using an applied magnetic field of 1000 Oe. The ac magnetic data were measured on a PPMS-9 ACMS magnetometer (Quantum Design, San Diego, CA, USA).

\subsection{Preparation}

All starting materials, except for $\mathrm{LnCl}_{3} \cdot 6 \mathrm{H}_{2} \mathrm{O}$, are commercially available and were used without further purification. $\mathrm{LnCl}_{3} \cdot 6 \mathrm{H}_{2} \mathrm{O}$ was prepared from the reaction of lanthanide oxide with a concentrated hydrochloric acid solution.

\subsubsection{Preparation of $\operatorname{PrCo}_{2}(\mathrm{~L} 1)_{7}(\text { bipy })_{2}(\mathbf{1})$}

A mixture containing $\mathrm{PrCl}_{3} \cdot 6 \mathrm{H}_{2} \mathrm{O}(0.07 \mathrm{~g}, 0.2 \mathrm{mmol}) \mathrm{Co}\left(\mathrm{NO}_{3}\right)_{2} \cdot 6 \mathrm{H}_{2} \mathrm{O}(0.06 \mathrm{~g}, 0.2 \mathrm{mmol})$, 4-chlorobenzoate (L1; $0.16 \mathrm{~g}, 1.0 \mathrm{mmol})$, bipy $(0.03 \mathrm{~g}, 0.2 \mathrm{mmol}), \mathrm{Na}_{2} \mathrm{CO}_{3}(0.05 \mathrm{mg}, 0.5 \mathrm{mmol})$, water $(10 \mathrm{~mL})$ and ethanol $(5 \mathrm{~mL})$ was sealed in a Teflon-lined stainless steel vessel $(23 \mathrm{~mL})$, which was heated at $160{ }^{\circ} \mathrm{C}$ for 3 days and then cooled to room temperature at a rate of $5{ }^{\circ} \mathrm{C} / \mathrm{h}$. Red block crystals of 1 were obtained and picked out, washed with distilled water and dried in air. Yield: $32 \%$ (based on $\mathrm{Co}(\mathrm{II})$ ). Elemental analysis for $\mathrm{C}_{69} \mathrm{H}_{44} \mathrm{Cl}_{7} \mathrm{Co}_{2} \mathrm{~N}_{4} \mathrm{O}_{14} \mathrm{Pr}(\%)$ Calcd.: C 49.92, H 2.67, N 3.38. Found: C 49.96, H 2.66, N 3.39. IR (KBr, $\left.\mathrm{cm}^{-1}\right)$ : 1611(vs), 1563(m), 1409(vs), 1166(m), 1094(m), 1010(m), 846(m), 768(s).

\subsubsection{Preparation of $\mathrm{LnCo}_{2}(\mathrm{~L} 1)_{7}(\text { bipy })_{2}(\mathrm{Ln}=\mathrm{Eu}, \mathrm{Sm}, \mathrm{Gd}, \mathrm{Tb}$, Dy) (2-6)}

The same synthetic procedure as that of 1 was used except that $\mathrm{PrCl}_{3} \cdot 6 \mathrm{H}_{2} \mathrm{O}$ was replaced by $\mathrm{LnCl}_{3} \cdot 6 \mathrm{H}_{2} \mathrm{O}(0.06-0.08 \mathrm{~g}, 0.2 \mathrm{mmol})(\mathrm{Ln}=\mathrm{Eu}, \mathrm{Sm}, \mathrm{Gd}, \mathrm{Tb}, \mathrm{Dy})$. Red block crystals of 2-6 were obtained and picked out, washed with distilled water and dried in air. Yield: $41 \%$ of 2 . (based on $\mathrm{Co}(\mathrm{II}))$. Elemental analysis for $\mathrm{C}_{69} \mathrm{H}_{44} \mathrm{Cl}_{7} \mathrm{Co}_{2} \mathrm{~N}_{4} \mathrm{O}_{14} \mathrm{Eu}(\%)$ : Calcd.: $\mathrm{C} 49.59, \mathrm{H} 2.65, \mathrm{~N} 3.35$; Found: $\mathrm{C}$ 49.54, H 2.67, N 3.32. IR (KBr, cm $\left.{ }^{-1}\right)$ : 1610(vs), 1560(m), 1409(vs), 1165(m), 1093(m), 1011(m), 847(m), 768(s). Yield: $46 \%$ of 3 (based on $\mathrm{Co}(\mathrm{II})$ ). Elemental analysis for $\mathrm{C}_{69} \mathrm{H}_{44} \mathrm{Cl}_{7} \mathrm{Co}_{2} \mathrm{~N}_{4} \mathrm{O}_{14} \mathrm{Sm}(\%)$ Calcd.: C 49.64, H 2.66, N 3.36. Found: C 49.67, H 2.65, N 3.38. IR (KBr, cm $\left.{ }^{-1}\right)$ : 1611(vs), 1561(m), 1409(vs), 1165(m), 1094(m), 1010(m), 846(m), 768(s). Yield: 52\% of 4 (based on Co(II)). Elemental analysis for $\mathrm{C}_{69} \mathrm{H}_{44} \mathrm{Cl}_{7} \mathrm{Co}_{2} \mathrm{~N}_{4} \mathrm{O}_{14} \mathrm{Gd}(\%)$ : Calcd.: C, 49.44; $\mathrm{H}, 2.65 ; \mathrm{N}$, 3.34. Found: $\mathrm{C}, 49.48 ; \mathrm{H}, 2.69 ; \mathrm{N}, 3.36$. IR (KBr, $\left.\mathrm{cm}^{-1}\right)$ : 1610(vs), 1560(m), 1408(vs), 1165(m), 1093(m), 1011(m), 847(m), 768(s). Yield: 47\% of 5 (based on $\mathrm{Co}(\mathrm{II})$ ). Elemental analysis for $\mathrm{C}_{69} \mathrm{H}_{44} \mathrm{Cl}_{7} \mathrm{Co}_{2} \mathrm{TbN}_{4} \mathrm{O}_{14}$ (\%) Calcd.: $\mathrm{C}, 49.39 ; \mathrm{H}, 2.64 ; \mathrm{N}, 3.34$. Found: C, 49.44; H, 2.61; N, 3.37. IR (KBr, $\left.\mathrm{cm}^{-1}\right)$ : 1611(vs), 1561(m), 1408(vs), 1165(m), 1093(m), 1011(m), 846(m), 768(s). Yield: $47 \%$ of 6 (based on $\mathrm{Co}(\mathrm{II})$ ). Elemental analysis for $\mathrm{C}_{69} \mathrm{H}_{44} \mathrm{Cl}_{7} \mathrm{Co}_{2} \mathrm{~N}_{4} \mathrm{O}_{14} \mathrm{Dy}(\%)$ Calcd.: C49.28, H 2.64, N 3.33. Found: C 49.29, H 2.64, N 3.31. IR (KBr, cm $\left.{ }^{-1}\right)$ : 1611(vs), 1561(m), 1407(vs), 1165(m), 1095(m), 1010(m), 846(m), 770(s).

\subsubsection{Preparation of $\mathrm{Ln}_{2} \mathrm{Co}_{2}(\mathrm{~L} 2)_{10}(\text { bipy })_{2}(\mathrm{Ln}=\mathrm{Sm}, \mathrm{Gd}, \mathrm{Tb}, \mathrm{Dy}, \mathrm{Ho}, \mathrm{Er}, \mathrm{Yb})(\mathbf{7 - 1 3})$}

The same synthetic procedure as that for 1 was used except that $\mathrm{PrCl}_{3} \cdot 6 \mathrm{H}_{2} \mathrm{O}$ was replaced by $\mathrm{LnCl}_{3} \cdot 6 \mathrm{H}_{2} \mathrm{O}(0.07-0.09 \mathrm{~g}, 0.2 \mathrm{mmol})$, $\mathrm{L} 1$ was replaced by 2,4-dichlorobenzoate (L2; $0.19 \mathrm{~g}, 1.0 \mathrm{mmol}$ ). Red block crystals of 7-13 were obtained and picked out, washed with distilled water and dried in 
air. Yield: $37 \%$ of 7 (based on $\mathrm{Co}(\mathrm{II})$ ). Elemental analysis for $7, \mathrm{C}_{90} \mathrm{H}_{46} \mathrm{Cl}_{20} \mathrm{Co}_{2} \mathrm{~N}_{4} \mathrm{O}_{20} \mathrm{Sm}_{2}$ (\%) Calcd.: C, 41.09; H, 1.76; N, 2.13. Found: C, 41.03; H, 1.74; N, 2.11. IR (KBr, $\left.\mathrm{cm}^{-1}\right)$ : 3090(m), 1593(vs), 1476(m), 1418(s), 1105(m), 1053(m), 863(m), 790(m). Yield: 58\% of 8 (based on Co(II)). Elemental analysis for 8, $\mathrm{C}_{90} \mathrm{H}_{46} \mathrm{Cl}_{20} \mathrm{Co}_{2} \mathrm{~N}_{4} \mathrm{O}_{20} \mathrm{Gd}_{2}$ (\%) Calcd.: C, 40.87; $\mathrm{H}, 1.75 ; \mathrm{N}, 2.12$. Found: $\mathrm{C}, 40.83 ; \mathrm{H}$, 1.71; N, 2.17. IR (KBr, cm $\left.{ }^{-1}\right)$ : 3090(m), 1593(vs), 1476(m), 1418(s), 1097(m), 1046(m), 863(m), 790(s). Yield: $46 \%$ of 9 (based on $\mathrm{Co}(\mathrm{II})$ ). Elemental analysis for $9, \mathrm{C}_{90} \mathrm{H}_{46} \mathrm{Cl}_{20} \mathrm{Co}_{2} \mathrm{~N}_{4} \mathrm{O}_{20} \mathrm{~Tb}_{2}$ (\%) Calcd.: $\mathrm{C}$, 40.82; H, 1.75; N, 2.12. Found: C, 40.79; H, 1.71; N, 2.14. IR (KBr, $\left.\mathrm{cm}^{-1}\right): 3090(\mathrm{~m}), 1593(\mathrm{vs}), 1476(\mathrm{~m})$, 1418(s), 1097(m), 1046(m), 863(m), 790(s). Yield: 45\% of 10 (based on Co(II)). Elemental analysis for $10 \mathrm{C}_{90} \mathrm{H}_{46} \mathrm{Cl}_{20} \mathrm{Co}_{2} \mathrm{~N}_{4} \mathrm{O}_{20} \mathrm{Dy}_{2}$ (\%) Calcd.: $\mathrm{C}, 40.71 ; \mathrm{H}, 1.75 ; \mathrm{N}, 2.11$. Found: $\mathrm{C}, 40.67 ; \mathrm{H}, 1.71 ; \mathrm{N}, 2.14$. IR (KBr, cm $\left.{ }^{-1}\right)$ : 3090(m), 1593(vs), 1476(m), 1418(s), 1097(m), 1046(m), 863(m), 789(s). Yield: 48\% of 11 (based on $\mathrm{Co}(\mathrm{II})$ ). Elemental analysis for $11, \mathrm{C}_{90} \mathrm{H}_{46} \mathrm{Cl}_{20} \mathrm{Co}_{2} \mathrm{~N}_{4} \mathrm{O}_{20} \mathrm{Ho}_{2}(\%)$ Calcd.: $\mathrm{C}$, 40.64; $\mathrm{H}$, 1.74; N, 2.11. Found: C, 40.61; H, 1.69; N, 2.15. IR (KBr, $\left.\mathrm{cm}^{-1}\right)$ : 3090(m), 1593(vs), 1475(m), 1418(s), 1104(m), 1053(m), 863(m), 784(m). Yield: $51 \%$ of 12 (based on Co(II)). Elemental analysis for 12, $\mathrm{C}_{90} \mathrm{H}_{46} \mathrm{Cl}_{20} \mathrm{Co}_{2} \mathrm{~N}_{4} \mathrm{O}_{20} \mathrm{Er}_{2}$ (\%) Calcd.: $\mathrm{C}, 40.56 ; \mathrm{H}, 1.74 ; \mathrm{N}, 2.10$. Found: $\mathrm{C}, 40.52 ; \mathrm{H}, 1.71 ; \mathrm{N}, 2.13$. IR $\left(\mathrm{KBr}, \mathrm{cm}^{-1}\right)$ : 3090(m), 1593(vs), 1476(m), 1418(s), 1097(m), 1046(m), 863(m), 789(s). Yield: 36\% of 13 (based on $\mathrm{Co}(\mathrm{II})$ ). Elemental analysis for $13, \mathrm{C}_{90} \mathrm{H}_{46} \mathrm{Cl}_{20} \mathrm{Co}_{2} \mathrm{Yb}_{2} \mathrm{~N}_{4} \mathrm{O}_{20}$ (\%)Calcd.: C 40.39, H 1.73, N2.09. Found: C 40.35, H 1.77, N 2.13. IR (KBr, cm $\left.{ }^{-1}\right)$ : 3090(m), 1593(vs), 1476(m), 1417(s), 1097(m), 1046(m), 865(m), 790(s).

\subsubsection{Preparation of $\mathrm{Ln}_{2} \mathrm{Co}_{3}(\mathrm{~L} 1)_{12}(\text { bipy })_{2}(\mathrm{Ln}=\mathrm{Ho}, \mathrm{Er}, \mathrm{Yb})(\mathbf{1 4}-\mathbf{1 6})$}

The same synthetic procedure as that for 1 was used except that $\mathrm{PrCl}_{3} \cdot 6 \mathrm{H}_{2} \mathrm{O}$ was replaced by $\mathrm{LnCl}_{3} \cdot 6 \mathrm{H}_{2} \mathrm{O}$ ( $\left.\mathrm{Ln}=\mathrm{Ho}, \mathrm{Er}, \mathrm{Yb} ; 0.09 \mathrm{~g}, 0.2 \mathrm{mmol}\right)$. Red block crystals of 14-16 were obtained and picked out, washed with distilled water and dried in air. Yield: $51 \%$ of $\mathbf{1 4}$ (based on Co(II)). Elemental analysis for 14, $\mathrm{C}_{104} \mathrm{H}_{64} \mathrm{Cl}_{12} \mathrm{Co}_{3} \mathrm{Ho}_{2} \mathrm{~N}_{4} \mathrm{O}_{24}$ (\%) Calcd.: C46.51, H 2.40, N 2.09; Found: $\mathrm{C} 46.53, \mathrm{H}$ 2.39, N 2.11. IR $\left(\mathrm{KBr}, \mathrm{cm}^{-1}\right)$ : 1593(vs), 1540(m), 1407(vs), 1281(m), 1171(m), 1093(m), 1011(m), 858(m), 774(m). Yield: $55 \%$ of 15 (based on $\mathrm{Co}(\mathrm{II})$ ). Elemental analysis for 15, $\mathrm{C}_{52} \mathrm{H}_{32} \mathrm{Cl}_{6} \mathrm{Co}_{1.5} \mathrm{ErN}_{2} \mathrm{O}_{12}$ (\%) Calcd.: $\mathrm{C} 46.43$, H 2.40, N 2.08. Found: C 46.41, H 2.43, N 2.12. IR (KBr, cm $\left.{ }^{-1}\right)$ : $1593(\mathrm{vs}), 1540(\mathrm{~m}), 1411(\mathrm{vs}), 1280(\mathrm{~m})$, 1171(m), 1094(m), 1010(m), 858(m), 773(m). Yield: 38\% of 16 (based on Co(II)). Elemental analysis for 16, $\mathrm{C}_{104} \mathrm{H}_{64} \mathrm{Cl}_{12} \mathrm{Co}_{3} \mathrm{Yb}_{2} \mathrm{~N}_{4} \mathrm{O}_{24}$ (\%) Calcd.: $\mathrm{C} 46.23, \mathrm{H}$ 2.39, N 2.07; Found: $\mathrm{C} 46.25, \mathrm{H}$ 2.32, N 2.04. IR $\left(\mathrm{KBr}, \mathrm{cm}^{-1}\right):$ 1593(vs), 1540(m), 1413(s), 1276(m), 1173(m), 1089(m), 1010(m), 857(m), 768(s).

\subsection{X-ray Crystallographic Determinations}

Single crystal analyses were performed on the RAXIS-RAPID AUTO CCD diffractometer systems (MoK $\alpha$ radiation, $\lambda=0.71073 \AA$ ) for 1-18. All data were corrected for absorption by the semiempirical method using the SADABS program. The program SAIN was applied for integration of the diffraction profiles [21]. Data analyses were carried out with the program XPREP. The structures were solved with the direct method using SHELXS-2014 followed by structure refinement on $\mathrm{F}^{2}$ with the program SHELXL-2014 [22]. All nonhydrogen atoms were refined anisotropically. Aromatic hydrogen atoms were assigned to calculated positions with isotropic thermal parameters. Crystal data and experimental details are summarized in Tables 1-5. Selected bonds and angles are listed in Tables S1-S3.

Table 1. Crystal data and structure refinement information for 1-3.

\begin{tabular}{cccc}
\hline Compound & $\mathbf{1}$ & $\mathbf{2}$ & $\mathbf{3}$ \\
\hline Empirical formula & $\mathrm{C}_{69} \mathrm{H}_{44} \mathrm{Cl}_{7} \mathrm{Co}_{2} \mathrm{~N}_{4} \mathrm{O}_{14} \mathrm{Pr}$ & $\mathrm{C}_{69} \mathrm{H}_{44} \mathrm{Cl}_{7} \mathrm{Co}_{2} \mathrm{~N}_{4} \mathrm{O}_{14} \mathrm{Eu}$ & $\mathrm{C}_{69} \mathrm{H}_{44} \mathrm{Cl}_{7} \mathrm{Co}_{2} \mathrm{~N}_{4} \mathrm{O}_{14} \mathrm{Sm}$ \\
$\mathrm{Fw}$ & 1660.00 & 1671.05 & 1669.45 \\
Temperature (K) & $293(2)$ & $293(2)$ & $293(2)$ \\
Crystal system & Triclinic & Triclinic & Triclinic \\
Space group & $P \overline{1}$ & $\overline{-}$ & $P \overline{1}$ \\
$\mathrm{a}(\AA)$ & $11.476(2)$ & $11.545(2)$ & $11.734(2)$ \\
$\mathrm{b}(\AA)$ & $13.762(3)$ & $13.651(3)$ & $13.617(3)$ \\
\hline
\end{tabular}


Table 1. Cont.

\begin{tabular}{cccc}
\hline Compound & $\mathbf{1}$ & $\mathbf{2}$ & $\mathbf{3}$ \\
\hline $\mathrm{c}\left(\AA^{\circ}\right)$ & $21.363(4)$ & $21.169(4)$ & $21.542(4)$ \\
$\alpha\left(^{\circ}\right)$ & $80.87(3)$ & $99.16(3)$ & $80.12(3)$ \\
$\beta\left(^{\circ}\right)$ & $89.82(3)$ & $90.04(3)$ & $89.88(3)$ \\
$\gamma\left({ }^{\circ}\right)$ & $89.18(3)$ & $90.98(3)$ & $89.99(3)$ \\
$\mathrm{V}\left(\AA^{3}\right)$ & $3330.8(11)$ & $3293.2(11)$ & $3391.0(11)$ \\
$\mathrm{Z}$ & 2 & 2 & 2 \\
$\mathrm{~F}(000)$ & 1660 & 1668 & 1666 \\
$D\left(\mathrm{Mg} / \mathrm{m}^{3}\right)$ & 1.655 & 1.685 & 1.635 \\
$\mathrm{Abs}$ coeff $\left(\mathrm{mm}^{-1}\right)$ & 1.562 & 1.793 & 1.682 \\
Data $/$ restraints $/$ params & $15,554 / 0 / 874$ & $15,461 / 0 / 874$ & $15,927 / 486 / 920$ \\
$\mathrm{GOF}$ & 0.999 & 1.004 & 1.031 \\
$\mathrm{R}_{1}{ }^{a}(\mathrm{I}=2 \sigma(\mathrm{I}))$ & 0.0734 & 0.0398 & 0.0582 \\
$\mathrm{WR}_{2}{ }^{\mathrm{a}}$ (all data) & 0.1669 & 0.1004 & 0.1373 \\
\hline
\end{tabular}

${ }^{\mathrm{a}} \mathrm{R}_{1}=\Sigma|| \mathrm{F}_{\mathrm{o}}|-| \mathrm{F}_{\mathrm{c}}|| /\left|\mathrm{F}_{\mathrm{o}}\right|, \mathrm{wR}_{2}=\left[\Sigma \mathrm{w}\left(\mathrm{F}_{\mathrm{o}}{ }^{2}-\mathrm{F}_{\mathrm{c}}{ }^{2}\right)^{2} / \Sigma \mathrm{w}\left(\mathrm{F}_{\mathrm{o}}{ }^{2}\right)^{2}\right]^{1 / 2}$.

Table 2. Crystal data and structure refinement information for 4-6.

\begin{tabular}{|c|c|c|c|}
\hline Compound & 4 & 5 & 6 \\
\hline Empirical formula & $\mathrm{C}_{69} \mathrm{H}_{44} \mathrm{Cl}_{7} \mathrm{Co}_{2} \mathrm{~N}_{4} \mathrm{O}_{14} \mathrm{Gd}$ & $\mathrm{C}_{69} \mathrm{H}_{44} \mathrm{Cl}_{7} \mathrm{Co}_{2} \mathrm{~N}_{4} \mathrm{O}_{14} \mathrm{~Tb}$ & $\mathrm{C}_{69} \mathrm{H}_{44} \mathrm{Cl}_{7} \mathrm{Co}_{2} \mathrm{~N}_{4} \mathrm{O}_{14} \mathrm{Dy}$ \\
\hline FW & 1676.34 & 1678.02 & 1681.59 \\
\hline Temperature (K) & $293(2)$ & $293(2)$ & $293(2)$ \\
\hline Crystal system & Triclinic & Triclinic & Triclinic \\
\hline Space group & $P \overline{1}$ & $P \overline{1}$ & $P \overline{1}$ \\
\hline $\mathrm{a}(\AA)$ & $11.769(2)$ & $11.783(2)$ & $11.608(2)$ \\
\hline$b(\AA)$ & $13.587(3)$ & $13.584(3)$ & $13.596(3)$ \\
\hline$c(\AA)$ & $21.539(4)$ & $21.484(4)$ & $21.107(4)$ \\
\hline$\alpha\left({ }^{\circ}\right)$ & $80.09(3)$ & $80.06(3)$ & $99.23(3)$ \\
\hline$\beta\left(^{\circ}\right)$ & $89.73(3)$ & $89.77(3)$ & $90.12(3)$ \\
\hline$\gamma\left({ }^{\circ}\right)$ & $89.97(3)$ & $89.95(3)$ & $90.94(3)$ \\
\hline $\mathrm{V}\left(\AA^{3}\right)$ & $3392.8(11)$ & $3387.1(11)$ & $3287.5(11)$ \\
\hline $\mathrm{Z}$ & 2 & 2 & 2 \\
\hline $\mathrm{F}(000)$ & 1670 & 1672 & 1674 \\
\hline $\mathrm{D}\left(\mathrm{Mg} / \mathrm{m}^{3}\right)$ & 1.641 & 1.645 & 1.699 \\
\hline Abs coeff $\left(\mathrm{mm}^{-1}\right)$ & 1.793 & 1.861 & 1.978 \\
\hline Data/restraints/params & $11,687 / 1512 / 920$ & $15,502 / 0 / 920$ & $15,419 / 0 / 874$ \\
\hline GOF & 1.008 & 1.039 & 0.979 \\
\hline $\mathrm{R}_{1}^{\mathrm{a}}(\mathrm{I}=2 \sigma(\mathrm{I}))$ & 0.0785 & 0.0429 & 0.0461 \\
\hline $\mathrm{WR}_{2}{ }^{\mathrm{a}}$ (all data) & 0.1684 & 0.0914 & 0.1001 \\
\hline
\end{tabular}

${ }^{\mathrm{a}} \mathrm{R}_{1}=\Sigma|| \mathrm{F}_{\mathrm{o}}|-| \mathrm{F}_{\mathrm{c}}|| /\left|\mathrm{F}_{\mathrm{o}}\right|, \mathrm{wR}_{2}=\left[\Sigma \mathrm{w}\left(\mathrm{F}_{\mathrm{o}}{ }^{2}-\mathrm{F}_{\mathrm{c}}{ }^{2}\right)^{2} / \Sigma \mathrm{w}\left(\mathrm{F}_{\mathrm{o}}{ }^{2}\right)^{2}\right]^{1 / 2}$.

Table 3. Crystal data and structure refinement information for 7-10.

\begin{tabular}{|c|c|c|c|c|}
\hline Compound & 7 & 8 & 9 & 10 \\
\hline $\begin{array}{l}\text { Empirical formula } \\
\text { Fw }\end{array}$ & $\begin{array}{c}\mathrm{C}_{90} \mathrm{H}_{46} \mathrm{Cl}_{20} \mathrm{Co}_{2} \mathrm{Sm}_{2} \mathrm{~N}_{4} \mathrm{O}_{20} \\
2630.87\end{array}$ & $\begin{array}{c}\mathrm{C}_{90} \mathrm{H}_{46} \mathrm{Cl}_{20} \mathrm{Co}_{2} \mathrm{Gd}_{2} \mathrm{~N}_{4} \mathrm{O}_{20} \\
2644.67\end{array}$ & $\begin{array}{c}\mathrm{C}_{90} \mathrm{H}_{46} \mathrm{Cl}_{20} \mathrm{Co}_{2} \mathrm{~Tb}_{2} \mathrm{~N}_{4} \mathrm{O}_{20} \\
2648.01\end{array}$ & $\begin{array}{c}\mathrm{C}_{90} \mathrm{H}_{46} \mathrm{Cl}_{20} \mathrm{Co}_{2} \mathrm{Dy}_{2} \mathrm{~N}_{4} \mathrm{O}_{20} \\
2655.17\end{array}$ \\
\hline Temperature (K) & $293(2)$ & $293(2)$ & $293(2)$ & $293(2)$ \\
\hline Crystal syst. & Triclinic & Triclinic & Triclinic & Triclinic \\
\hline Space group & $P \overline{1}$ & $P \overline{1}$ & $P \overline{1}$ & $P \overline{1}$ \\
\hline $\mathrm{a}(\AA)$ & $12.998(3)$ & 13.411(3) & $13.421(3)$ & $13.048(3)$ \\
\hline$b(\AA)$ & $13.914(3)$ & 13.804(3) & $13.786(3)$ & $13.774(3)$ \\
\hline$c(\AA)$ & $14.241(3)$ & $13.809(3)$ & $13.806(3)$ & $13.809(3)$ \\
\hline$\alpha\left(^{\circ}\right)$ & 101.41(3) & $98.96(3)$ & $99.04(3)$ & $99.20(3)$ \\
\hline$\beta\left(^{\circ}\right)$ & $97.92(3)$ & $107.45(3)$ & $95.86(3)$ & $95.81(3)$ \\
\hline$\gamma\left({ }^{\circ}\right)$ & $106.52(3)$ & $95.93(3)$ & $107.45(3)$ & $107.60(3)$ \\
\hline$V\left(\AA^{3}\right)$ & 2368.3(9) & 2378.3(9) & 2376.2(9) & $2305.5(9)$ \\
\hline Z & 1 & 1 & 1 & 1 \\
\hline $\mathrm{F}(000)$ & 1292 & 1296 & 1298 & 1300 \\
\hline$D\left(\mathrm{Mg} / \mathrm{m}^{3}\right)$ & 1.845 & 1.847 & 1.850 & 1.912 \\
\hline Abs coeff $\left(\mathrm{mm}^{-1}\right)$ & 2.203 & 2.353 & 2.448 & 2.610 \\
\hline Data/restraints/params & $11,077 / 0 / 623$ & $11,128 / 0 / 623$ & $11,077 / 0 / 623$ & $11,038 / 0 / 623$ \\
\hline GOF & 0.953 & 1.014 & 0.953 & 0.886 \\
\hline $\mathrm{R}_{1}^{\mathrm{a}}(\mathrm{I}=2 \sigma(\mathrm{I}))$ & 0.0326 & 0.0294 & 0.0326 & 0.0274 \\
\hline $\mathrm{WR}_{2}{ }^{\mathrm{a}}$ (all data) & 0.0704 & 0.0634 & 0.0704 & 0.0668 \\
\hline
\end{tabular}

\footnotetext{
${ }^{\mathrm{a}} \mathrm{R}_{1}=\Sigma|| \mathrm{F}_{\mathrm{o}}|-| \mathrm{F}_{\mathrm{c}}|| /\left|\mathrm{F}_{\mathrm{o}}\right|, \mathrm{wR}_{2}=\left[\Sigma \mathrm{w}\left(\mathrm{F}_{\mathrm{o}}^{2}-\mathrm{F}_{\mathrm{c}}^{2}\right)^{2} / \Sigma \mathrm{w}\left(\mathrm{F}_{\mathrm{o}}{ }^{2}\right)^{2}\right]^{1 / 2}$.
} 
Table 4. Crystal data and structure refinement information for 11-13.

\begin{tabular}{cccc}
\hline Compound & $\mathbf{1 1}$ & $\mathbf{1 2}$ & $\mathbf{1 3}$ \\
\hline Empirical formula & $\mathrm{C}_{90} \mathrm{H}_{46} \mathrm{Cl}_{20} \mathrm{Co}_{2} \mathrm{Ho}_{2} \mathrm{~N}_{4} \mathrm{O}_{20}$ & $\mathrm{C}_{90} \mathrm{H}_{46} \mathrm{Cl}_{20} \mathrm{Co}_{2} \mathrm{Er}_{2} \mathrm{~N}_{4} \mathrm{O}_{20}$ & $\mathrm{C}_{90} \mathrm{H}_{46} \mathrm{Cl}_{20} \mathrm{Co}_{2} \mathrm{Yb}_{2} \mathrm{~N}_{4} \mathrm{O}_{20}$ \\
$\mathrm{Fw}$ & 2660.03 & 2664.69 & 2676.25 \\
Temperature $(\mathrm{K})$ & $293(2)$ & $293(2)$ & $293(2)$ \\
Crystal syst. & Triclinic & Triclinic & Triclinic \\
Space group & - & $P 1$ & $-\overline{1}$ \\
$\mathrm{a}(\AA)$ & $13.425(3)$ & $13.397(3)$ & $13.503(3)$ \\
$\mathrm{b}(\AA)$ & $13.774(3)$ & $13.741(3)$ & $13.801(3)$ \\
$\mathrm{c}(\AA)$ & $13.802(3)$ & $13.877(3)$ \\
$\alpha\left(^{\circ}\right)$ & $13.821(3)$ & $99.44(3)$ & $99.98(3)$ \\
$\beta\left(^{\circ}\right)$ & $99.27(3)$ & $95.77(3)$ & $95.65(3)$ \\
$\gamma\left({ }^{\circ}\right)$ & $95.79(3)$ & $107.65(3)$ & $107.71(3)$ \\
$\mathrm{V}\left(\AA^{3}\right)$ & $107.66(3)$ & $2357.7(9)$ & $2394.5(9)$ \\
$\mathrm{Z}$ & $2372.8(9)$ & 1 & 1 \\
$\mathrm{~F}(000)$ & 1 & 1304 & 1308 \\
$\mathrm{D}\left(\mathrm{Mg} / \mathrm{m}^{3}\right)$ & 1302 & 1.877 & 1.856 \\
$\mathrm{Abs}$ coeff $\left(\mathrm{mm}^{-1}\right)$ & 1.862 & 2.747 & 2.905 \\
Data/restraints/params & 2.629 & $11,051 / 0 / 623$ & $10,813 / 0 / 622$ \\
$\mathrm{GOF}$ & $11,021 / 0 / 623$ & 0.987 & 1.036 \\
$\mathrm{R}_{1}{ }^{\mathrm{a}}(\mathrm{I}=2 \sigma(\mathrm{I}))$ & 0.993 & 0.0317 & 0.0379 \\
$\mathrm{WR}_{2}{ }^{\mathrm{a}}$ (all data) & 0.0402 & 0.0710 & 0.0874 \\
\hline
\end{tabular}

${ }^{\mathrm{a}} \mathrm{R}_{1}=\Sigma|| \mathrm{F}_{\mathrm{o}}|-| \mathrm{F}_{\mathrm{c}}|| /\left|\mathrm{F}_{\mathrm{o}}\right|, \mathrm{wR}_{2}=\left[\Sigma \mathrm{w}\left(\mathrm{F}_{\mathrm{o}}^{2}-\mathrm{F}_{\mathrm{c}}^{2}\right)^{2} / \Sigma \mathrm{w}\left(\mathrm{F}_{\mathrm{o}}^{2}\right)^{2}\right]^{1 / 2}$.

Table 5. Crystal data and structure refinement information for 14-16.

\begin{tabular}{|c|c|c|c|}
\hline Compound & 14 & 15 & 16 \\
\hline $\begin{array}{l}\text { Empirical formula } \\
\text { FW }\end{array}$ & $\begin{array}{c}\mathrm{C}_{104} \mathrm{H}_{64} \mathrm{Cl}_{12} \mathrm{Co}_{3} \mathrm{Ho}_{2} \mathrm{~N}_{4} \mathrm{O}_{24} \\
2685.64\end{array}$ & $\begin{array}{c}\mathrm{C}_{104} \mathrm{H}_{64} \mathrm{Cl}_{12} \mathrm{Co}_{3} \mathrm{Er}_{2} \mathrm{~N}_{4} \mathrm{O}_{24} \\
2690.30\end{array}$ & $\begin{array}{c}\mathrm{C}_{104} \mathrm{H}_{64} \mathrm{Cl}_{12} \mathrm{Co}_{3} \mathrm{Yb}_{2} \mathrm{~N}_{4} \mathrm{O}_{24} \\
2701.86\end{array}$ \\
\hline Temperature (K) & $293(2)$ & $293(2)$ & $293(2)$ \\
\hline Crystal syst. & Triclinic & Triclinic & Triclinic \\
\hline Space group & $P \overline{1}$ & $P \overline{1}$ & $P \overline{1}$ \\
\hline $\mathrm{a}(\AA)$ & $13.900(3)$ & 13.893(3) & $13.702(3)$ \\
\hline $\mathrm{b}(\AA)$ & $14.772(3)$ & $14.824(3)$ & $14.600(3)$ \\
\hline$c(\AA)$ & $16.034(3)$ & $16.073(3)$ & $15.895(3)$ \\
\hline$\alpha\left(^{\circ}\right)$ & $105.01(3)$ & $105.25(3)$ & $105.13(3)$ \\
\hline$\beta\left(^{\circ}\right)$ & $103.74(3)$ & $103.61(3)$ & $103.46(3)$ \\
\hline$\gamma\left({ }^{\circ}\right)$ & $113.66(3)$ & $113.49(3)$ & $113.30(3)$ \\
\hline$V\left(\AA^{3}\right)$ & $2687.0(16)$ & $2703.9(9)$ & 2608.9(9) \\
\hline $\mathrm{Z}$ & 1 & 1 & 1 \\
\hline $\mathrm{F}(000)$ & 1327 & 1329 & 1333 \\
\hline $\mathrm{D}\left(\mathrm{Mg} / \mathrm{m}^{3}\right)$ & 2.280 & 1.652 & 1.720 \\
\hline Abs coeff $\left(\mathrm{mm}^{-1}\right)$ & 2.448 & 2.354 & 2.624 \\
\hline data/restraints/params & $12,585 / 0 / 683$ & $12,603 / 0 / 683$ & $12,324 / 6 / 683$ \\
\hline GOF & 1.001 & 0.998 & 1.006 \\
\hline $\mathrm{R} 1 \mathrm{a}(\mathrm{I}=2 \sigma(\mathrm{I}))$ & 0.0500 & 0.0461 & 0.0468 \\
\hline WR2a (all data) & 0.1127 & 0.1111 & 0.1056 \\
\hline
\end{tabular}

${ }^{\mathrm{a}} \mathrm{R}_{1}=\Sigma|| \mathrm{F}_{\mathrm{o}}|-| \mathrm{F}_{\mathrm{c}}|| /\left|\mathrm{F}_{\mathrm{o}}\right|, \mathrm{wR}_{2}=\left[\Sigma \mathrm{w}\left(\mathrm{F}_{\mathrm{o}}{ }^{2}-\mathrm{F}_{\mathrm{c}}{ }^{2}\right)^{2} / \Sigma \mathrm{w}\left(\mathrm{F}_{\mathrm{o}}{ }^{2}\right)^{2}\right]^{1 / 2}$

\section{Result and Discussion}

\subsection{Description of the Structures}

\subsubsection{Crystal Structures of Compounds 1-6}

The single crystal X-ray analysis revealed that compounds 1-6 are isostructural. They crystallize in the triclinic $P \overline{1}$ space group and consist of quasi linear trinuclear metal ions. Hence, only the structure 
of 5 is described in detail. As described in Figure 1a, the structure of 5 contains one $\mathrm{Tb}(\mathrm{III})$ ion (Tb1), two crystallographically independent $\mathrm{Co}$ (II) ions (Co1 and Co2), and seven 4-chlorobenzoate ligands and two crystallographically independent bipy ligands. The coordination environment of the metal ions (Tb1, Co1 and Co2) in 5 is presented in Figure 1b. Co1 is six-coordinated with distorted octahedron geometry, composed of four carboxylic $\mathrm{O}$ atoms $(\mathrm{O} 1, \mathrm{O} 3, \mathrm{O} 5, \mathrm{O} 6)$ from three different L1 ligands and two $\mathrm{N}$ atoms $(\mathrm{N} 1, \mathrm{~N} 2)$ from one bipy ligand $(\mathrm{Co} 1-\mathrm{O}=2.026(2)-2.370(3) \AA, \mathrm{Co} 1-\mathrm{N}=2.094(3)-2.154(3)$ $\AA)$. The Co2 ion is also six-coordinated with a slightly distorted octahedral coordination environment, composed of four carboxylic $\mathrm{O}$ atoms $(\mathrm{O} 7, \mathrm{O} 9, \mathrm{O} 11, \mathrm{O} 12)$ from three different L1 ligands and two $\mathrm{N}$ atoms $(\mathrm{N} 3, \mathrm{~N} 4)$ from one bipy ligand $(\mathrm{Co} 2-\mathrm{O}=1.980(3)-2.401(3) \AA$, Co2-N = 2.098(3)-2.128(3) $\AA)$. The Tb1 ion is located on the crystallographic inversion centre and is eight-coordinated with the distorted dodecahedron coordination geometry, as depicted in Figure 2, composed of eight carboxylic $\mathrm{O}$ atoms from seven different L1 ligands (Tb1-O = 2.326(2)-2.497(2) A ). Two bridging $\mu-1,2$ [bis(monodentate)] carboxylate groups and one $\mu-1,1,2$ [bidentate-monodentate] carboxylate group link the $\mathrm{Tb}(\mathrm{III})$ ion and $\mathrm{Co}(\mathrm{II})$ together (Tb1-Co = 3.7977(13)-3.8508(9) $\AA$, Co1-Tb1-Co2 = $\left.150.573(13)^{\circ}\right)$. There are three coordinated modes of the L1 ligands in 5: two bridging (a) $\mu$-1,2 [bis(monodentate)] and (b) $\mu-1,1,2$ [bidentate-monodentate] and chelating (c) bidentate, as depicted in Scheme 1. Two bipy ligands are located on the two ends as the terminal ligands.

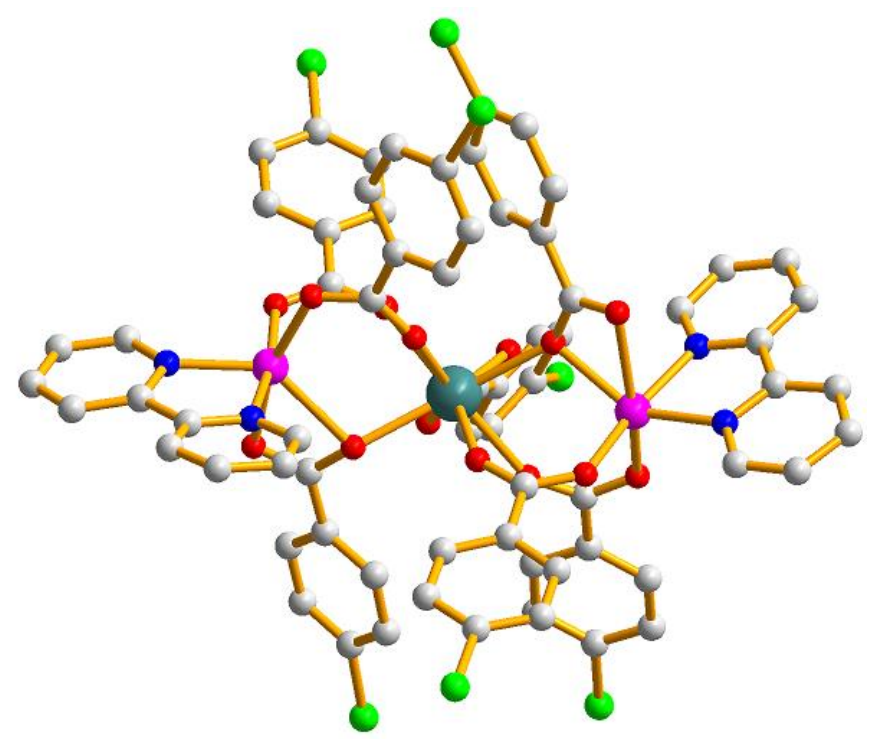

(a)

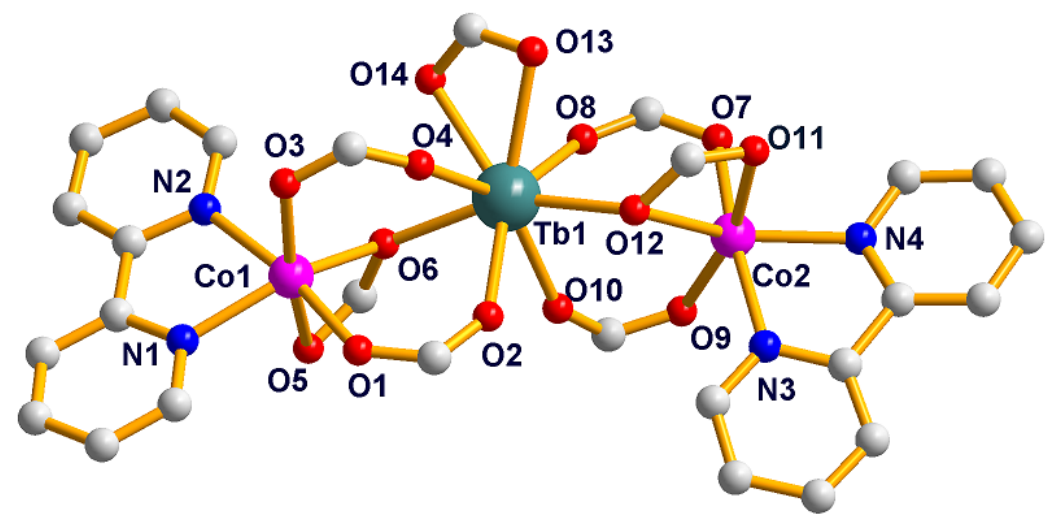

(b)

Figure 1. (a) The molecule structure of the trinuclear $\left[\mathrm{TbCo}_{2}(\mathrm{~L} 1)_{7}(\mathrm{bipy})_{2}\right]$ of 5 . Hydrogen atoms are omitted for clarity. (b) The coordination environments of the metal centers in $\mathbf{5}$. 


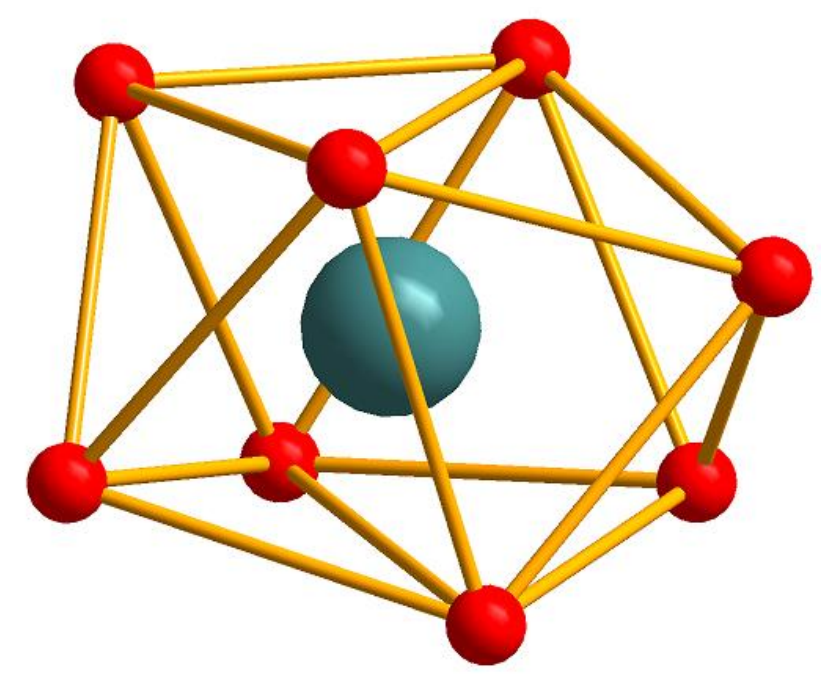

Figure 2. The distorted dodecahedron coordination geometry of $\mathrm{Tb}(\mathrm{III})$ ion in $\mathbf{5}$ with the $\mathrm{TbO}_{8}$ sphere.<smiles>[M]OC(=O)c1ccc(Cl)cc1</smiles>

a<smiles>[M]OC(O[M])c1ccc(Cl)cc1</smiles>

$b$<smiles>Clc1ccc(C2=NO2)cc1</smiles>

$\mathrm{C}$

Scheme 1. The coordinated modes of the L1 ligands in 5.

\subsubsection{Crystal Structures of Compounds $7-13$}

The single crystal X-ray analysis revealed that compounds 7-13 are isostructural. They crystallize in the triclinic $P \overline{1}$ space group and consist of linear tetranuclear metal ions. Hence, only the structure of $\mathbf{8}$ is described in detail. As presented in Figure 3a, the structure of $\mathbf{8}$ contains two symmetry related Gd(III) ions (Gd1, Gd1a) ( $a=-x,-y, 1-z)$, two symmetry related Co(II) ions (Co1 and Co1a) and ten symmetry related L2 ligands and two symmetry related bipy ligands. The coordination environment of the metal ions (Gd1, Gd1a, Co1 and Co1a) in 8 is presented in Figure 3b. Co1 is six-coordinated with distorted octahedron geometry, composed of four carboxylic $\mathrm{O}$ atoms $(\mathrm{O} 1, \mathrm{O} 2, \mathrm{O} 8, \mathrm{O} 9)$ from three different $\mathrm{L} 2$ ligands and two $\mathrm{N}$ atoms (N1, N2) from one bipy ligand (Co1-O = 2.0096(19)-2.1374(19) $\AA, \mathrm{Co} 1-\mathrm{N}=2.073(2)-2.144(2) \AA)$. The Gd1 ion is seven-coordinated with the distorted mono-capped trigonal prismatic coordination geometry, as depicted in Figure 4, and is composed of seven carboxylic O atoms from seven different $\mathrm{L} 2$ ligands (Gd1-O = 2.304(2)-2.3752(19) $\AA$ ). Two bridging $\mu-1,2$ [bis(monodentate)] carboxylate groups and one $\mu-1,1,2$ [bidentate-monodentate] carboxylate group link the Gd1(III) ion and Co1(II) ion together (Gd1-Co1 $=4.0404(20) \AA)$. Four bridging $\mu-1,2$ [bis(monodentate)] carboxylate groups link two symmetry related Gd1 and Gd1a together (Gd1-Gd1a $=4.3862(20) \AA)$; two symmetry related Co(II) ions are located at the two sides of the two symmetry related Gd(III) ion $\left(\mathrm{Co} 1-\mathrm{Co} 1 \mathrm{a}=12.4559(59) \AA, \mathrm{Co1}-\mathrm{Gd} 1-\mathrm{Gd} 1 \mathrm{a}=174.907(14)^{\circ}\right) . \mathrm{Co1}-\mathrm{Gd} 1-\mathrm{Gd} 1 \mathrm{a}-\mathrm{Co} 1 \mathrm{a}$ is arranged almost linearly, and the paddlewheel type of ligand can be seen when the molecules are viewed along the Co1-Gd1-Gd1a-Co1a $(a=-x,-y, 1-z)$ axis (Figure 5). The two symmetry-related bipy ligands are located on the two ends as the terminal ligands. 


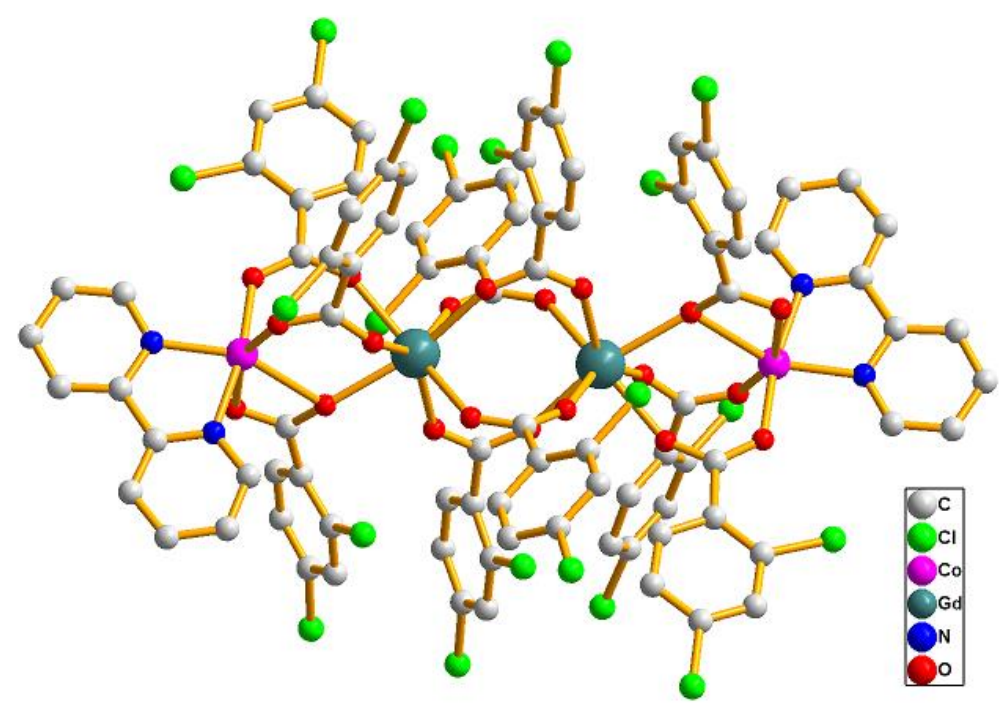

(a)

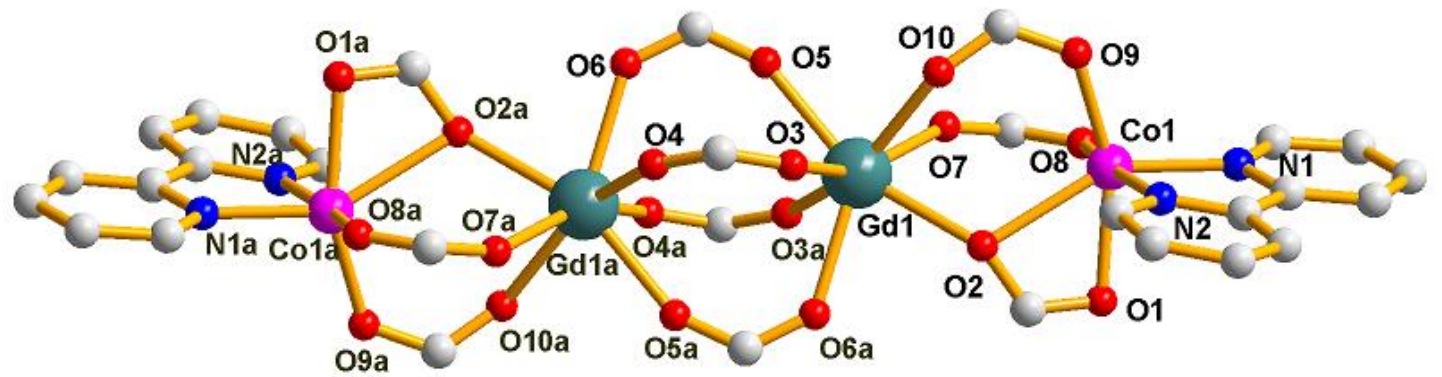

(b)

Figure 3. (a) The molecule structure of the tetranuclear $\left[\mathrm{Gd}_{2} \mathrm{Co}_{2}(\mathrm{~L} 2)_{10}(\text { bipy })_{2}\right]$ of 8 . Hydrogen atoms are omitted for clarity. (b) The coordination environments of the metal centers in 8.

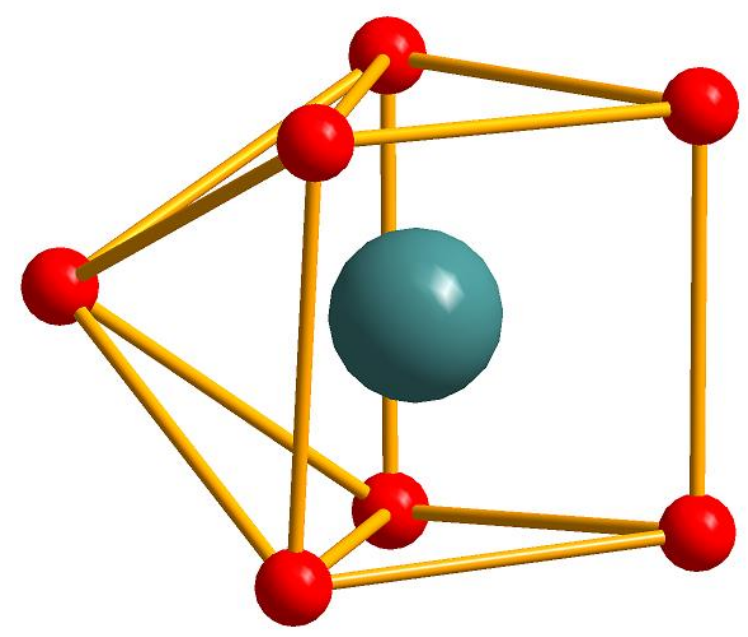

Figure 4. The distorted Capped Trigonal Prismatic coordination geometry of the Gd(III) ion in $\mathbf{8}$ with the $\mathrm{GdO}_{7}$ sphere. 


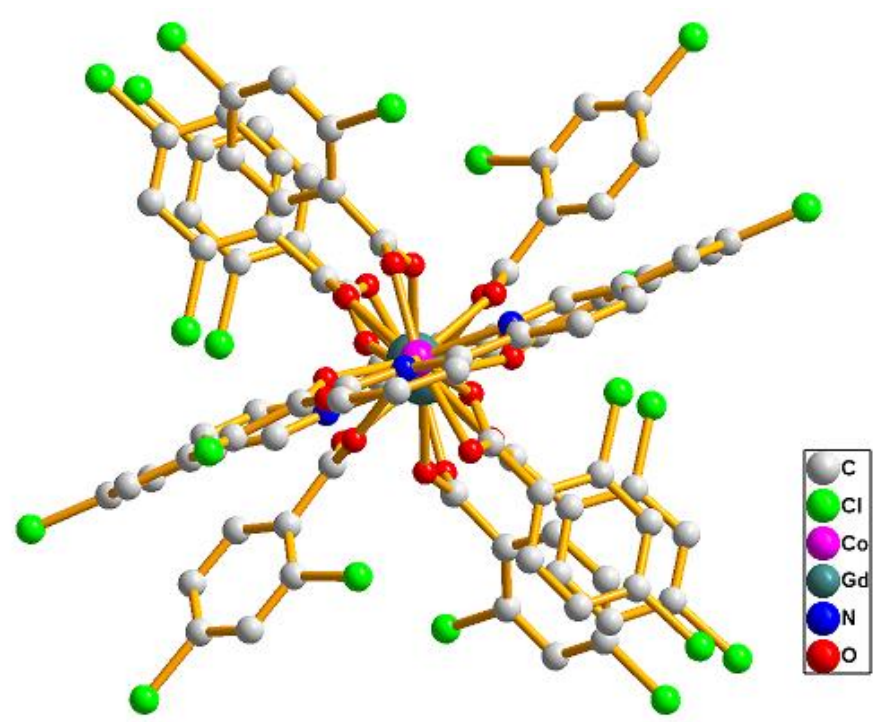

Figure 5. The paddlewheel arrangement of the ligands viewed along the Co1-Gd1-Gd1a-Co1a axis in 8.

\subsubsection{Crystal Structures of Compounds $\mathbf{1 4}-\mathbf{1 6}$}

The single crystal X-ray analysis reveals that compounds 14-16 are isostructural. They crystallize in the triclinic $P \overline{1}$ space group and consist of quasi-linear pentanuclear metal ions. Hence, only the structure of $\mathbf{1 4}$ is described in detail. As presented in Figure 6a, the asymmetric unit of $\mathbf{1 4}$ contains two symmetry related $\mathrm{Ho}(\mathrm{III})$ ions (Ho1, Ho1a), three $\mathrm{Co}$ (II) ions (Co1, Co1a and Co2) and twelve symmetry related L1 ligands and two symmetry related bipy ligands. The coordination environment of the metal ions (Ho1, Ho1a, Co1, Co1a and Co2) in $\mathbf{1 4}$ is presented in Figure 6b. The Co2(II) ion is located on the crystallographic inversion center, which is six-coordinated with distorted octahedron geometry, composed of six carboxylic O atoms (O7, O7a, O9, O9a, O11, O11a) from six different L1 ligands $(\mathrm{Co} 2-\mathrm{O}=2.010(3)-2.167(3) \AA)$. The Ho1 ion is eight-coordinated with a distorted square anti-prism coordination geometry, as depicted in Figure 7, and is composed of eight carboxylic $\mathrm{O}$ atoms from six different L1 ligands (Ho1-O = 2.239(4)-2.580(3) $\AA$ ). One bridging $\mu-1,2$ [bis(monodentate)] carboxylate group and two $\mu-1,1,2$ [bidentate-monodentate] carboxylate groups link the Ho1(III) ion and Co2(II) ion together $\left(\mathrm{Ho}-\mathrm{Co} 2=3.6673(17) \AA\right.$, $\left.\mathrm{Ho} 1-\mathrm{Co} 2-\mathrm{Ho} 1 \mathrm{a}=180.00^{\circ}\right)$. Co1 is six-coordinated with distorted octahedron geometry, and is composed of three carboxylic $\mathrm{O}$ atoms $(\mathrm{O} 1, \mathrm{O} 3, \mathrm{O} 5)$ from three different L1 ligands and two N atoms (N1, N2) from one bipy ligand (Co1-O = 2.010(3)-2.051(3) $\AA, \mathrm{Co1}-\mathrm{N}=$ 2.077(4)-2.142(4) $\AA$ ). The three bridging $\mu-1,2$ [bis(monodentate)] carboxylate group links Ho1 and Co1 together $\left(\mathrm{Ho} 1-\mathrm{Co} 1=4.0210(22) \AA, \mathrm{Co} 1-\mathrm{Ho} 1-\mathrm{Co} 2=162.073(18)^{\circ}\right)$. Co1-Ho1-Co2-Ho1a-Co1a is arranged almost linearly; the paddlewheel type of ligand can be seen when the molecules are viewed along the Co1-Ho1-Co2-Ho1a-Co1a $(a=2-x, 1-y, 1-z)$ axis (Figure S1). The two symmetry related bipy ligands are located on the two ends as the terminal ligands. The pentanuclear compounds reported in the literature are mostly concentrated in the 3d metal region [23-26], and the pentanuclear compounds of $3 \mathrm{~d}-\mathbf{4} \mathbf{f}$ heterometallic metals are relatively few [27-29]. In the reported $3 \mathrm{~d}-\mathbf{4 f}$ pentanuclear compounds, the arrangement shapes of pentanuclear metals can be roughly divided into the following types: (a) Trigonal-bipyramidal type [30], (b) Goblet-like [31], (c) Butterfly-shaped [32], (d) Open-book type [33], (e) T-shaped [34] and (f) Sandwich-type [35]. Only one case is similar to the linear structure reported in this paper [36]. 


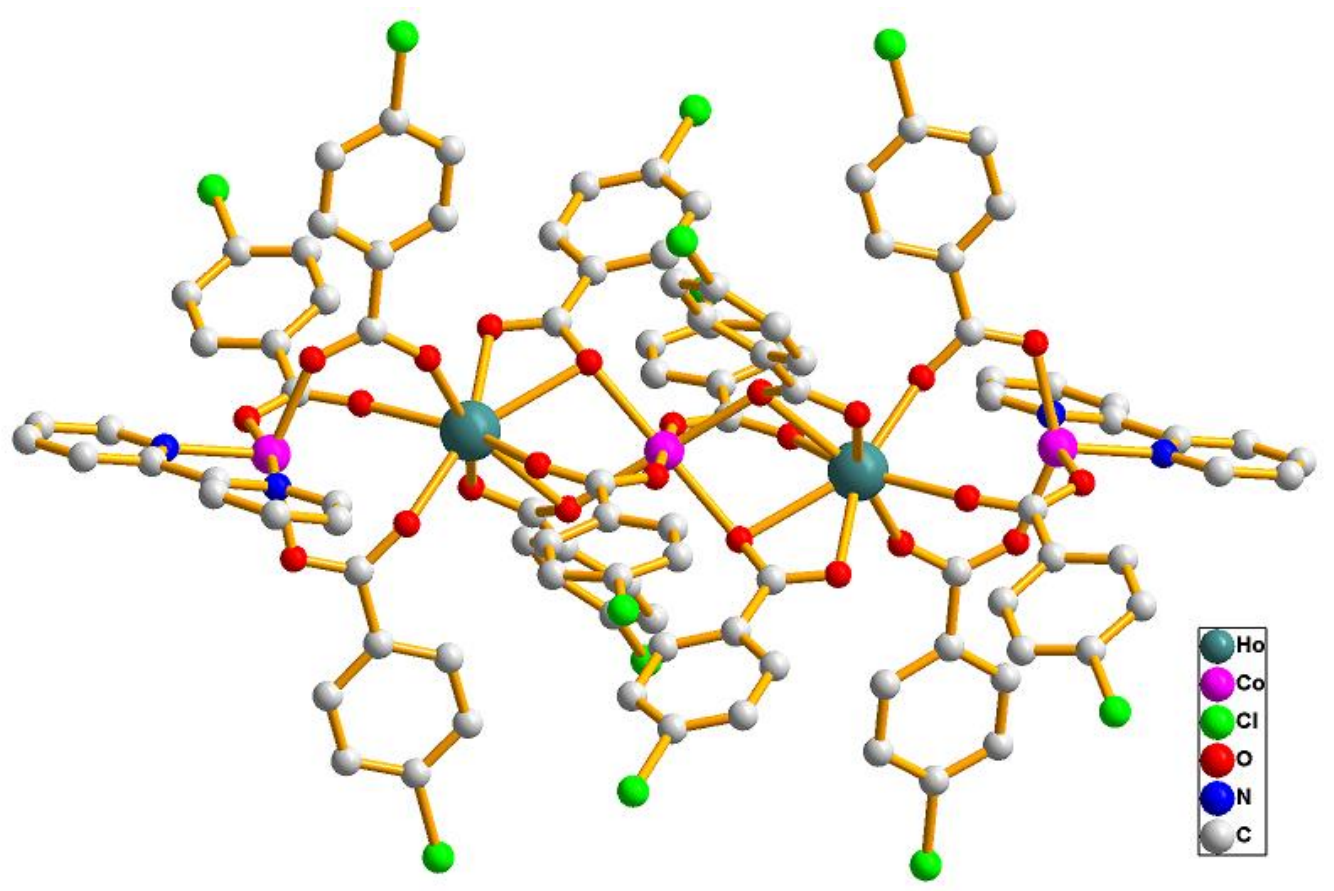

(a)

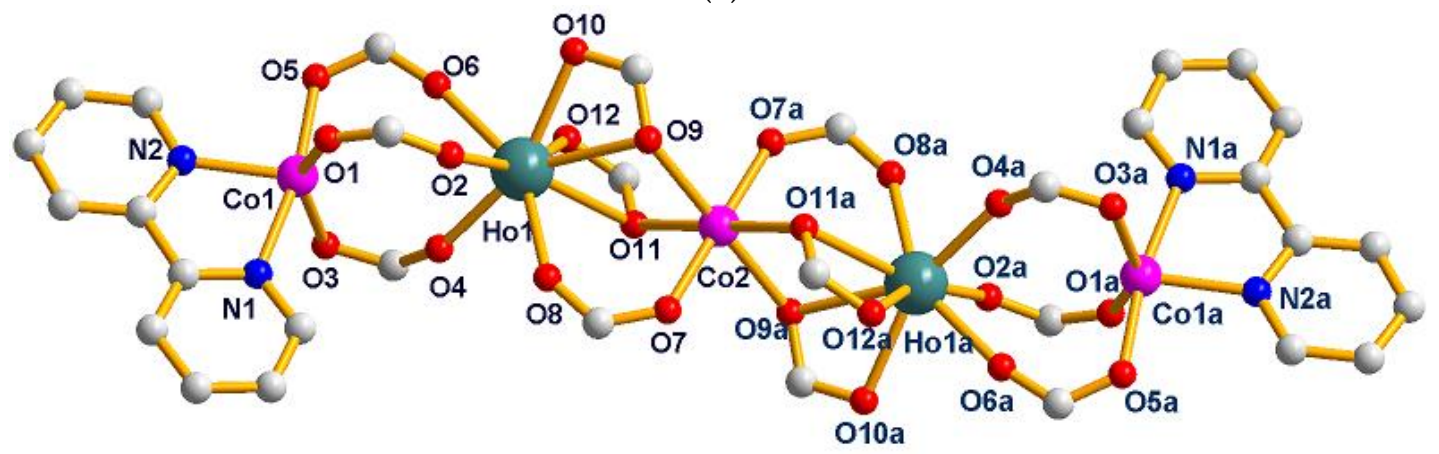

(b)

Figure 6. (a) The molecule structure of the pentanuclear $\left[\mathrm{Ho}_{2} \mathrm{Co}_{3}(\mathrm{~L} 1)_{12}(\text { bipy })_{2}\right]$ of $\mathbf{1 4}$. Hydrogen atoms are omitted for clarity. (b) The coordination environments of the metal centers in $\mathbf{1 4 .}$

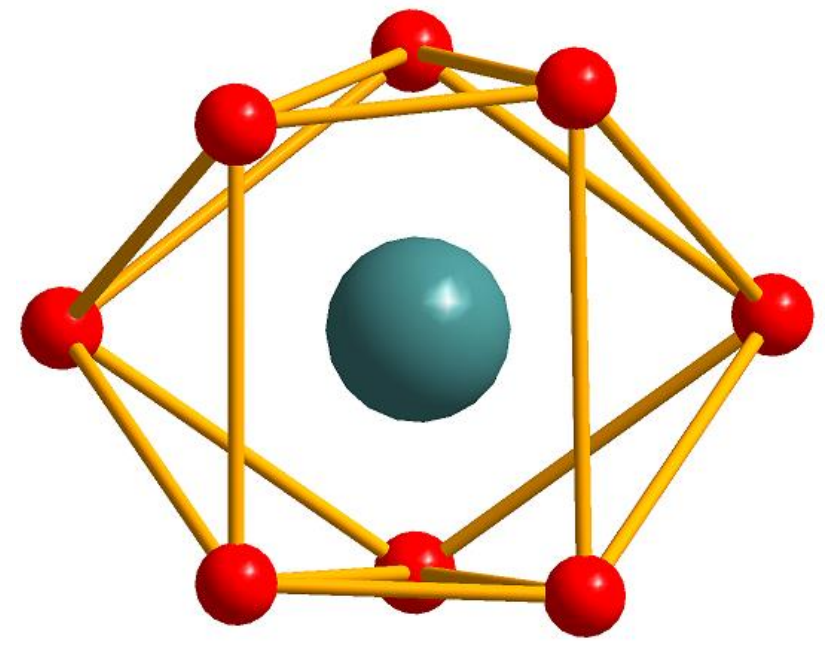

Figure 7. The distorted square antiprism coordination geometry of $\mathrm{Ho}(\mathrm{III})$ ion in $\mathbf{1 4}$ with the $\mathrm{HoO}_{8}$ sphere. 
The differences between the three types of structures may be ascribed to the stereo-hindrance effect of the carboxylate ligands and the different radii of $\operatorname{Ln}(\mathrm{III})$ ions.

\subsection{Magnetic Properties}

Magnetic susceptibility measurements were carried out on polycrystalline samples of 3-18 in the temperature range of $2-300 \mathrm{~K}$ at $1000 \mathrm{Oe}$. The basic magnetic data derived from these measurements are listed in Table 6 . The small discrepancies between the calculated and theoretical values of $\chi_{\mathrm{m}} \mathrm{T}$ might be ascribed to the orbital contribution of the metal ion. This phenomenon is quite common in the literature [37-41]. Their calculated $\chi_{\mathrm{m}} \mathrm{T}$ values are also close to those of compounds with similar structures [42].

Table 6. Summary of static magnetic properties of the three series of heterometallic compounds 3-14.

\begin{tabular}{|c|c|c|c|c|c|}
\hline & $3\left(\mathrm{SmCo}_{2}\right)$ & $4\left(\mathrm{GdCo}_{2}\right)$ & $5\left(\mathrm{DyCo}_{2}\right)$ & $6\left(\mathrm{TbCo}_{2}\right)$ & $7\left(\mathrm{Sm}_{2} \mathrm{Co}_{2}\right)$ \\
\hline Ground state of Ln(III) & ${ }^{6} \mathrm{H}_{5 / 2}$ & ${ }^{8} S_{7 / 2}$ & ${ }^{6} \mathrm{H}_{15 / 2}$ & ${ }^{7} \mathrm{~F}_{6}$ & ${ }^{6} \mathrm{H}_{5 / 2}$ \\
\hline$\chi_{\mathrm{m}} \mathrm{T}$ (theoretical) & 3.84 & 11.63 & 17.92 & 15.57 & 3.93 \\
\hline$\chi_{\mathrm{m}} \mathrm{T}$ (observed) & 5.16 & 13.05 & 18.52 & 17.54 & 4.74 \\
\hline $\mathrm{C}\left(\mathrm{emu} \mathrm{mol} \mathrm{mol}^{-1} \mathrm{~K}\right)$ & 5.16 & 12.83 & 18.48 & 17.38 & 4.32 \\
\hline \multirow[t]{2}{*}{$\theta(\mathrm{K})$} & -0.33 & 7.05 & 2.03 & 3.89 & 29.09 \\
\hline & $8\left(\mathrm{Gd}_{2} \mathrm{Co}_{2}\right)$ & $9\left(\mathrm{~Tb}_{2} \mathrm{Co}_{2}\right)$ & $10\left(\mathrm{Dy}_{2} \mathrm{Co}_{2}\right)$ & $11\left(\mathrm{Ho}_{2} \mathrm{Co}_{2}\right)$ & $12\left(\mathrm{Er}_{2} \mathrm{Co}_{2}\right)$ \\
\hline Ground state of Ln(III) & ${ }^{8} S_{7 / 2}$ & ${ }^{7} \mathrm{~F}_{6}$ & ${ }^{6} \mathrm{H}_{15 / 2}$ & ${ }^{5} \mathrm{I}_{8}$ & ${ }^{4} \mathrm{I}_{15 / 2}$ \\
\hline$\chi_{\mathrm{m}} \mathrm{T}$ (theoretical) & 19.51 & 27.39 & 32.09 & 31.89 & 26.71 \\
\hline$\chi_{\mathrm{m}} \mathrm{T}$ (observed) & 20.23 & 28.76 & 32.24 & 33.40 & 26.82 \\
\hline $\mathrm{C}\left(\mathrm{emu} \mathrm{mol}{ }^{-1} \mathrm{~K}\right)$ & 19.81 & 27.38 & 32.18 & 34.58 & 26.66 \\
\hline \multirow[t]{2}{*}{$\theta(\mathrm{K})$} & 7.14 & 15.49 & 2.36 & -9.29 & 2.11 \\
\hline & $13\left(\mathrm{Yb}_{2} \mathrm{Co}_{2}\right)$ & $14\left(\mathrm{Ho}_{2} \mathrm{Co}_{3}\right)$ & $15\left(\mathrm{Er}_{2} \mathrm{Co}_{3}\right)$ & $16\left(\mathrm{Yb}_{2} \mathrm{Co}_{3}\right)$ & \\
\hline Ground state of Ln(III) & ${ }^{2} \mathrm{~F}_{7 / 2}$ & ${ }^{5} \mathrm{I}_{8}$ & ${ }^{4} \mathrm{I}_{15 / 2}$ & ${ }^{2} \mathrm{~F}_{7 / 2}$ & \\
\hline$\chi_{\mathrm{m}} \mathrm{T}$ (theoretical) & 8.89 & 33.77 & 28.59 & 10.76 & \\
\hline$\chi_{\mathrm{m}} \mathrm{T}$ (observed) & 9.28 & 33.78 & 30.23 & 11.33 & \\
\hline $\mathrm{C}\left(\mathrm{emu} \mathrm{mol} \mathrm{mol}^{-1} \mathrm{~K}\right)$ & 9.66 & 33.04 & 30.97 & 11.11 & \\
\hline$\theta(\mathrm{K})$ & -11.87 & 12.54 & -6.23 & 8.01 & \\
\hline
\end{tabular}

\subsubsection{Magnetic Properties of Compounds 3-6}

The experimental $\chi_{\mathrm{m}} \mathrm{T}$ values at $300 \mathrm{~K}$ for the series of heterotrinuclear compounds 3-6 are 5.16, $13.05,18.52$ and $17.54 \mathrm{~cm}^{3} \cdot \mathrm{K} \cdot \mathrm{mol}^{-1}$, which are close to those expected for two uncoupled Co(II) ions $(\mathrm{S}=3 / 2, \mathrm{~g}=2)$ and one lanthanide metal ion: one $\mathrm{Sm}(\mathrm{IIII})\left(g_{\mathrm{J}}=2 / 7,{ }^{6} \mathrm{H}_{5 / 2}\right)$ for 3 , one $\mathrm{Gd}(\mathrm{III})\left(g_{\mathrm{J}}=2\right.$, $\left.{ }^{8} \mathrm{~S}_{7 / 2}\right)$ for 4 , one Dy(III) $\left(g_{\mathrm{J}}=4 / 3,{ }^{6} \mathrm{H}_{15 / 2}\right)$ for 5 , one $\mathrm{Tb}$ (III) $\left(g_{\mathrm{J}}=3 / 2,{ }^{7} \mathrm{~F}_{6}\right)$ for 6 . As shown in Figure 8 , the magnetic properties of the four compounds are relatively different when studied as a function of the temperature. When the temperature is decreased, the $\chi_{\mathrm{m}} \mathrm{T}$ value of 3 at 1000 Oe progressively decreases to reach $3.53 \mathrm{~cm}^{3} \cdot \mathrm{K} \cdot \mathrm{mol}^{-1}$ at $2 \mathrm{~K}$. In this situation, it is very difficult to interpret the magnetic properties of 3, because $\mathrm{Sm}$ (III) ions of this system have an orbital degenerate ground state which can cause the same feature. ${ }^{23}$ On the other hand, the $\chi_{\mathrm{m}} \mathrm{T}$ values of $\mathbf{4 , 5}$ and $\mathbf{6}$ at 1000 Oe continuously increase upon lowering the temperature to reach $13.53,19.52$ and $17.90 \mathrm{~cm}^{3} \cdot \mathrm{K} \cdot \mathrm{mol}^{-1}$, respectively, at $94 \mathrm{~K}, 50 \mathrm{~K}$ and $124 \mathrm{~K}$. For 4, the Gd(III) ion, whose f-f spin-orbit coupling effect is absent in the first order (for the ${ }^{8} \mathrm{~S}_{7 / 2}$ ground state), the influence of the ligand field can be safely neglected, and the increase of $\chi_{\mathrm{m}} \mathrm{T}$ value can be ascribed to the ferromagnetic interactions in this trinuclear compounds. For $\mathbf{5}$ and $\mathbf{6}$, the ground states of the $\mathrm{Dy}(\mathrm{III})$ and $\mathrm{Tb}(\mathrm{III})$ ions are ${ }^{6} \mathrm{H}_{15 / 2}$ and ${ }^{7} \mathrm{~F}_{6}$, respectively. Upon lowering the temperature, progressive depopulation of these levels occurs, and the increase of these $\chi_{\mathrm{m}} \mathrm{T}$ values may be ascribed to the ferromagnetic interactions among $\mathrm{Dy}(\mathrm{III}) / \mathrm{Tb}(\mathrm{III})$ and $\mathrm{Co}$ (II) ions in these trinuclear compounds [37]. At lower temperatures, $\chi_{m} T$ decreases in these cases. This is probably the result of magnetic anisotropy or weak antiferromagnetic interactions between trinuclear compounds. 

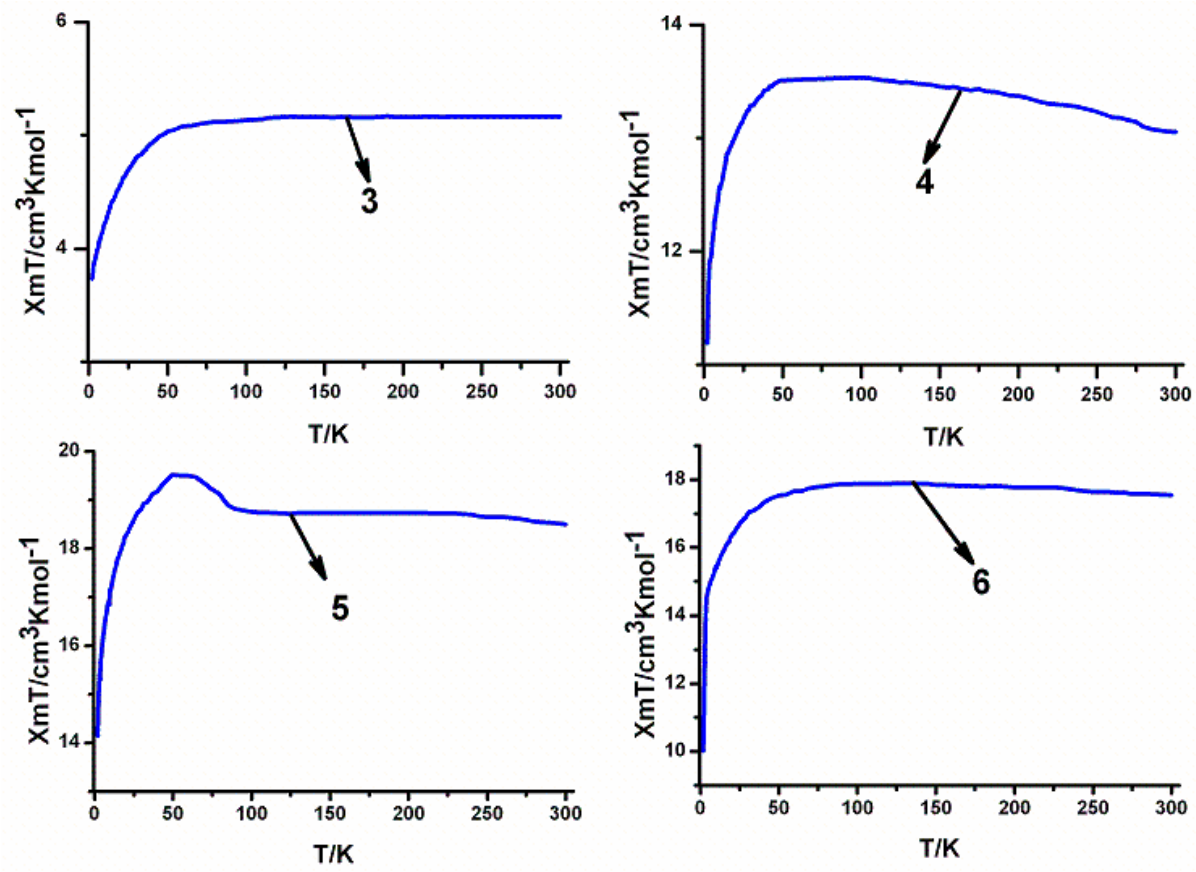

Figure 8. Temperature dependence of the $\chi_{m} \mathrm{~T}$ curves at 1000 Oe for the series of heterotrinuclear compounds 3-6.

\subsubsection{Magnetic Properties of Compounds $\mathbf{7 - 1 3}$}

The plots of $\chi_{\mathrm{m}} \mathrm{T}$ vs $\mathrm{T}$ for the heterotetranuclear compounds $\mathbf{7 - 1 3}$ are presented in Figure 9. The experimental $\chi_{\mathrm{m}} \mathrm{T}$ values at room temperature are 4.74, 20.23, 28.76, 32.24, 33.40, 26.82 and $9.28 \mathrm{~cm}^{3} \cdot \mathrm{K} \cdot \mathrm{mol}^{-1}$, which are close to those expected for noninteracting metal ions of two $\mathrm{Co}$ (II) ions $(S=3 / 2, g=2)$ and two lanthanide metal ions [3.93, 19.51, 27.39, 32.09, 31.89, 27.71 and $8.89 \mathrm{~cm}^{3} \cdot \mathrm{K} \cdot \mathrm{mol}^{-1}$ for 7-13 respectively]. As shown in Figure 9, the magnetic properties of the eight compounds are relatively different when studied as a function of the temperature. When the temperature is decreased, the $\chi_{\mathrm{m}} \mathrm{T}$ values of $7, \mathbf{9 , 1 0}$ and 12 at 1000 Oe continuously increase upon lowering the temperature to reach $5.30,20.89,34.10,32.80$ and $27.30 \mathrm{~cm}^{3} \cdot \mathrm{K} \cdot \mathrm{mol}^{-1}$, respectively, at $89 \mathrm{~K}$, $99 \mathrm{~K}, 48.9 \mathrm{~K}, 134 \mathrm{~K}$ and $48.9 \mathrm{~K}$. For 8, the Gd(III) ion, whose f-f spin-orbit coupling effect is absent in the first order (for the ${ }^{8} \mathrm{~S}_{7 / 2}$ ground state), the influence of the ligand field can be safely neglected, and the increase of $\chi_{\mathrm{m}} \mathrm{T}$ value can be ascribed to the ferromagnetic interactions in the these tetranuclear compounds. For 7, 9, 10 and 12, the ground states of the $\mathrm{Sm}(\mathrm{III}), \mathrm{Tb}(\mathrm{III}), \mathrm{Dy}(\mathrm{III})$ and $\mathrm{Er}$ (III) ions are ${ }^{6} \mathrm{H}_{5 / 2},{ }^{7} \mathrm{~F}_{6},{ }^{6} \mathrm{H}_{15 / 2}$ and ${ }^{4} \mathrm{I}_{15 / 2}$, respectively. Upon lowering the temperature, progressive depopulation of these levels occurs, and the increase of these $\chi_{\mathrm{m}} \mathrm{T}$ values may be ascribed to the ferromagnetic interactions among $\mathrm{Ln}(\mathrm{III})(\mathrm{Ln}=\mathrm{Sm}, \mathrm{Dy}, \mathrm{Tb}, \mathrm{Er})$ and $\mathrm{Co}(\mathrm{II})$ ions in these tetranuclear compounds [37]. At lower temperatures, $\chi_{\mathrm{m}} \mathrm{T}$ decreases in these cases, probably as the result of magnetic anisotropy or weak antiferromagnetic interactions between tetranuclear compounds. On the other hand, when the temperature is decreased, the $\chi_{\mathrm{m}} \mathrm{T}$ values of $\mathbf{1 1}$ and $\mathbf{1 3}$ at 1000 Oe progressively decrease to reach 24.68 and $7.18 \mathrm{~cm}^{3} \cdot \mathrm{K} \cdot \mathrm{mol}^{-1}$, respectively, at $2 \mathrm{~K}$ and $5.9 \mathrm{~K}$. In this situation, it is very difficult to interpret the magnetic properties of $\mathbf{1 1}$ and $\mathbf{1 3}$, because the $\mathrm{Ho}(\mathrm{III})$ and $\mathrm{Yb}$ (III) ions of these systems have an orbital degenerate ground state which can cause the same feature. 

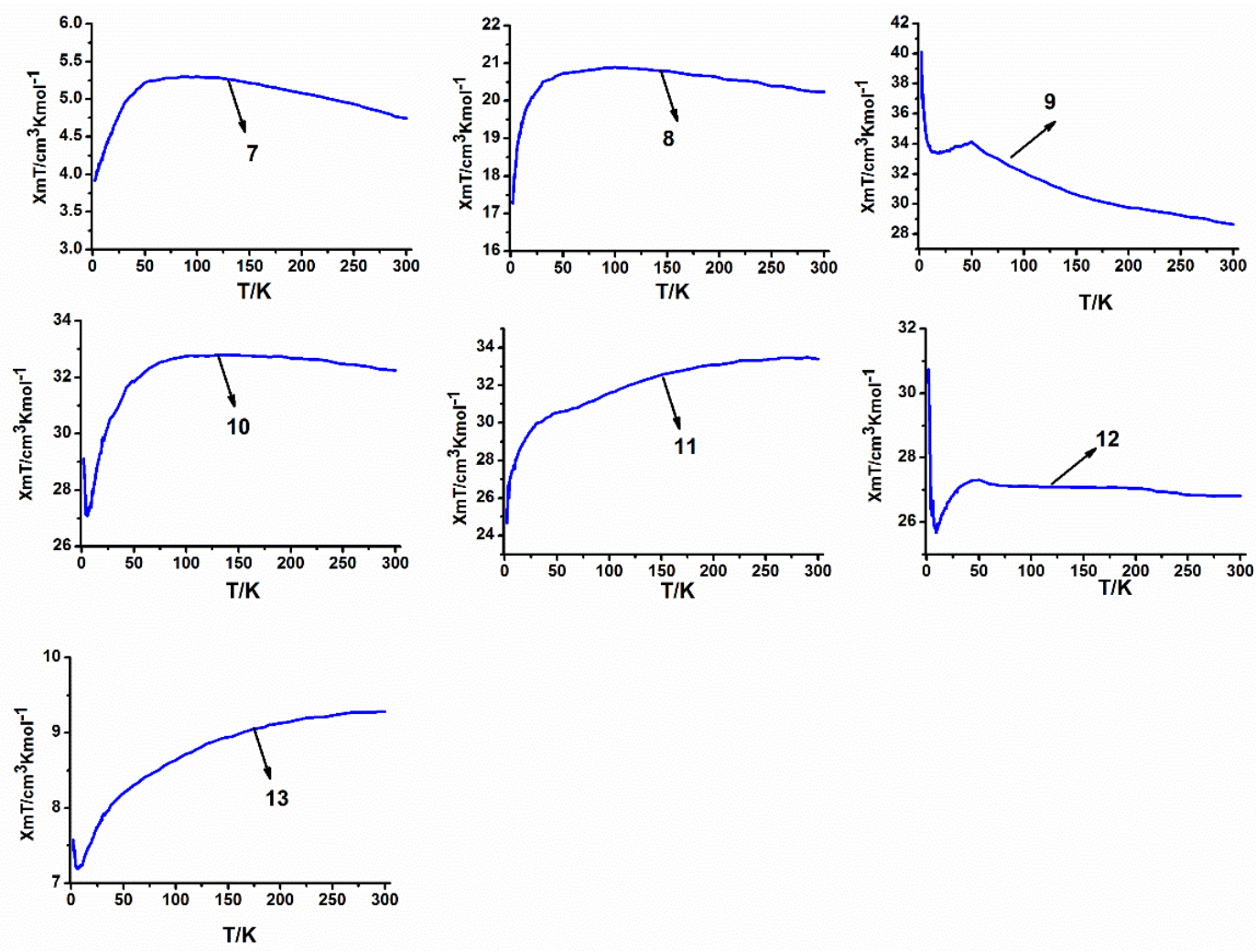

Figure 9. Temperature dependence of the $\chi_{\mathrm{m}} \mathrm{T}$ curves at 1000 Oe for the series of heterotetranuclear compounds 7-13.

We also synthesized the corresponding Y(III)-Co(II) heterometallic compounds (compound of 17 trinuclear and tetranuclear compound of 18) to do the accurate diamagnetic correction with the 4-chlorobenzoic acid and 2,4-dichlorobenzoic acid as ligands, respectively [43]. The crystal data of compounds 17 and 18 are listed in Table S4 in the Supporting Information. The plots of $\chi_{\mathrm{m}} \mathrm{T}$ vs $\mathrm{T}$ for 17 and 18 are shown in Figures S2 and S3 in the Supporting Information. The comparison between the isostructural Ln-Co and Y-Co compounds, which is defined as the function $\Delta\left(\chi_{m} T\right)=\left(\chi_{m} T\right)_{L n-C o}$ $-\left(\mathrm{X}_{\mathrm{m}} \mathrm{T}\right)_{\mathrm{Y}-\mathrm{Co}_{0}}$ may eliminate the crystal field contribution of Co ions. Thus, according to the change trend of $\Delta\left(\chi_{\mathrm{m}} \mathrm{T}\right)$ in the 2-300 K temperature range (Figures S4 and S5 in the Supporting Information), the ferromagnetic or antiferromagnetic coupling of $\mathrm{Ln}^{3+}$ would be clearly concluded. However, it is difficult to comment on the interactions of Co-Ln in these compounds, with the $\mathrm{Co}^{2+}$ and $\mathrm{Ln}^{3+}$ ions both having intrinsic complicated magnetic characteristics which include the presence of spin-orbit coupling and magnetic anisotropy.

\subsubsection{Magnetic Properties of Compounds 14-16}

The experimental $\chi_{\mathrm{m}} \mathrm{T}$ values at room temperature for the series of heteropentanuclear compounds [33.78, 30.23 and $11.33 \mathrm{~cm}^{3} \cdot \mathrm{K} \cdot \mathrm{mol}^{-1}$ for $\mathbf{1 4 - 1 6}$, respectively] are close to those expected for noninteracting metal ions of the three $\mathrm{Co}(\mathrm{II})$ ions $(S=3 / 2, g=2)$ and two lanthanide metal ions [33.77 $\mathrm{cm}^{3} \cdot \mathrm{K} \cdot \mathrm{mol}^{-1}$ for $14(\mathrm{Ho}), 28.59 \mathrm{~cm}^{3} \cdot \mathrm{K} \cdot \mathrm{mol}^{-1}$ for $15(\mathrm{Er})$ and 10.76 for $16(\mathrm{Yb})$ ]. As shown in Figure 10, the magnetic properties of the three compounds are relatively different when studied as a function of the temperature. When the temperature is decreased, the $\chi_{\mathrm{m}} \mathrm{T}$ values of $\mathbf{1 4}$ and $\mathbf{1 6}$ at 1000 Oe continuously increase upon lowering the temperature to reach 41.78 and $12.04 \mathrm{~m}^{3} \cdot \mathrm{K} \cdot \mathrm{mol}^{-1}$, respectively, at $22.9 \mathrm{~K}$ and $24.9 \mathrm{~K}$. For 14 , and 16, the ground states of the $\mathrm{Ho}$ (III) and $\mathrm{Yb}$ (III) ions are ${ }^{5} \mathrm{I}_{8}$ and ${ }^{2} \mathrm{~F}_{7 / 2}$, respectively. Upon lowering the temperature, progressive depopulation of these levels occurs, and the increase of these $\chi_{m} T$ value may be ascribed to the ferromagnetic interactions among $\mathrm{Ho}(\mathrm{III}), \mathrm{Yb}(\mathrm{III})$ and $\mathrm{Co}(\mathrm{II})$ ions in these pentanuclear compounds. At lower temperatures, 
$\chi_{\mathrm{m}} \mathrm{T}$ decreases in these cases, probably as the result of magnetic anisotropy or weak antiferromagnetic interactions between pentanuclear compounds. On the other hand, when the temperature is decreased, the $\chi_{\mathrm{m}} \mathrm{T}$ value of $\mathbf{1 5}$ at 1000 Oe progressively decreases to reach $21.27 \mathrm{~cm}^{3} \cdot \mathrm{K} \cdot \mathrm{mol}^{-1}$ at $2 \mathrm{~K}$. In this situation, it is very difficult to interpret the magnetic properties of 15 , because $\operatorname{Er}(\mathrm{III})$ ions of this system have an orbital degenerate ground state which can cause the same feature [37].
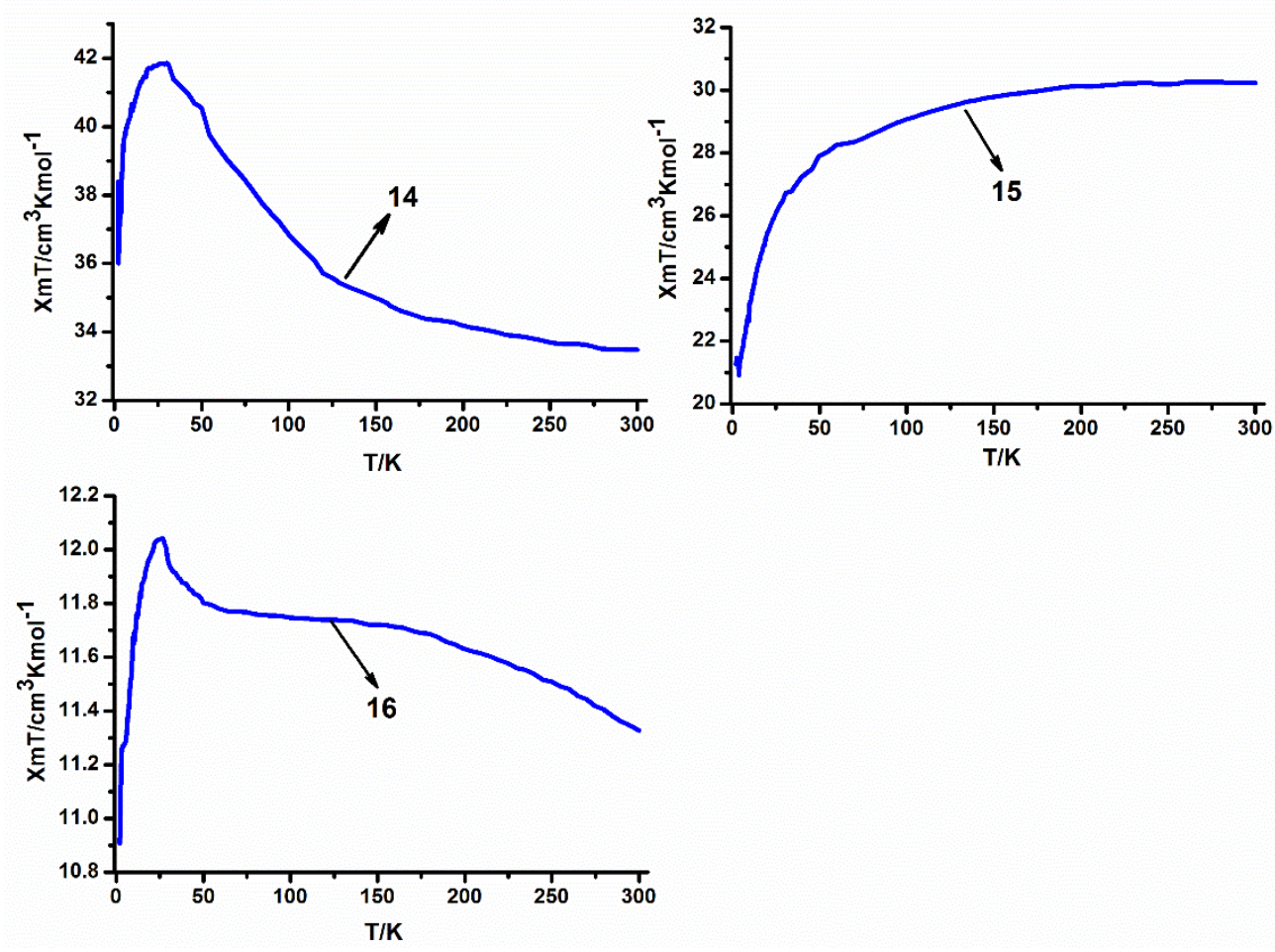

Figure 10. Temperature dependence of the $\chi_{m} \mathrm{~T}$ curves at 1000 Oe for the series of heteropentanuclear compounds 14-16.

To probe the presence of slow dynamics in these molecular systems and thus the presence of SMM behaviour, ac susceptibility measurements were performed systematically for compounds 5, 9 and $\mathbf{1 4}$. The measurements were collected at zero direct-current (dc) field with an ac field of 3 Oe. Unfortunately, only compound 14 displayed nonzero and rather smaller frequency-dependent out-of-phase signals (Figures S6 and S7 in the Supporting Information). Even so, this phenomenon should not be neglected, because the frequency-dependent out-of-phase signals often occur in Dy(III)-containing systems and are often suppressed by applying a static dc field [37], which is rarely reported in Ho(III)-containing compounds in a zero direct-current (dc) field.

\section{Conclusions}

In summary, eighteen $3 \mathrm{~d}-4 \mathrm{f}$ heterometallic coordination compounds were successfully synthesized under hydrothermal conditions. Structural analyses revealed that the eighteen compounds including three types, the compounds 1-6 and 17, are isostructural heterotrinuclear compounds, the compounds 7-13 and $\mathbf{1 8}$ are isostructural heterotetranuclear compounds and 14-16 are isostructural heteropentanuclear compounds. It is noteworthy that compound 14, which contains Ho(III) ions, presented field-induced slow magnetic relaxation. The successful preparation of these series of compounds provides valuable information for further construction of more $3 \mathrm{~d}-\mathbf{4 f}$ materials with novel magnetic properties.

Supplementary Materials: The following are available online at http:/ /www.mdpi.com/2073-4360/11/2/196/s1, CCDC-1887007 (for 1), 1887008 (for 2), 1887009 (for 3), 1887010 (for 4) 1887011 (for 5), 1887012 (for 6), 1887013 (for 7), 1887014 (for 8), CCDC-1887015 (for 9), 1887016 (for 10), 1887278 (for 11) and 1887279 (for 12), 1887280 
(for 13), 1887501 (for 14), 1887500 (for 15) 1887502 (for 16), 1887282 (for 17), and 1887283 (for 18) contain the supplementary crystallographic data for this paper. These data can be obtained free of charge from The Cambridge Crystallographic Data Centre via www.ccdc.cam.ac.uk/data_request/cif.

Author Contributions: Y.X. performed all the syntheses, control experiments, characterization, and she also summarized the data and the first draft of the article. F.L. proposed constructive amendments to the paper. This research project comes from J.-M.Z.'s thought. In addition, J.-M.Z. was responsible for the testing of single crystal structure and molecular magnetism. All authors have discussed the results presented and commented on the paper.

Funding: The authors would like to thank the National Natural Science Foundation of China (50872057) and the Natural Science Foundation of Anhui Educational Bureau (No. KJ2017A380) for the financial supports.

Conflicts of Interest: The authors declare no conflict of interest.

\section{References}

1. Sakamoto, M.; Manseki, K.; Ohkawa, H. d-f Heteronuclear complexes: Synthesis, structures and physicochemical aspects. Coord. Chem. Rev. 2001, 219-221, 379-414. [CrossRef]

2. Gu, Z.G.; Sevov, S.C. Syntheses, structures, and magnetic properties of heterometallic coordination polymers with carboxyphosphonate linkers. J. Mater. Chem. 2009, 19, 8442-8447. [CrossRef]

3. Mori, F.; Nyui, T.; Ishida, T.; Nogami, T.; Choi, K.Y.; Nojiri, H. Oximate-Bridged Trinuclear Dy-Cu-Dy Complex Behaving as a Single-Molecule Magnet and Its Mechanistic Investigation. J. Am. Chem. Soc. 2006, 128, 1440-1441. [CrossRef] [PubMed]

4. Prasad, T.K.; Rajasekharan, M.V.; Costes, J.P. A Cubic 3d-4f Structure with Only Ferromagnetic Gd-Mn Interactions. Angew. Chem. Int. Ed. 2007, 46, 2851-2854. [CrossRef] [PubMed]

5. Heras Ojea, M.J.; Milway, V.A.; Velmurugan, G.; Thomas, L.H.; Coles, S.J.; Wilson, C.; Wernsdorfer, W.; Rajaraman, G.; Murrie, M. Enhancement of TbIII-CuII Single-Molecule Magnet Performance. Chem. Eur. J. 2016, 22, 1-11. [CrossRef]

6. Xin, N.; Sun, Y.Q.; Zheng, Y.F.; Xu, Y.Y.; Gao, D.Z.; Zhang, G.Y. Seven 3d-4f coordination polymers of macrocyclic oxamide with polycarboxylates: Syntheses, crystal structures and magnetic properties. J. Solid State Chem. 2016, 243, 267-275. [CrossRef]

7. Zhang, J.W.; Ren, Y.N.; Li, J.X.; Liu, B.Q.; Dong, Y.P. Syntheses, structures, and magnetic properties of two series of $3 \mathrm{~d}-4 \mathrm{f}$ heterometallic coordination polymers derived from pyrazine-2,3-dicarboxylic acid. Eur. J. Inorg. Chem. 2018, 2018, 1099-1106. [CrossRef]

8. Cheng, J.W.; Zhang, J.; Zheng, S.T.; Zhang, M.B.; Yang, G.Y. Lanthanide-Transition-Metal Sandwich Framework Comprising \{Cu3\} Cluster Pillars and Layered Networks of $\{$ Er36\} Wheels. Angew. Chem. Int. Ed. 2005, 45, 73-77. [CrossRef]

9. Zhang, S.W.; Cheng, P. Magnetocaloric Effect of Two Isostructural Heterometallic Organic Frameworks Based on \{MIIGdIII2 $\}$ Clusters (where MII = Mn and Ni). ChemPlusChem 2016, 81, 811-816. [CrossRef]

10. Ren, Y.P.; Long, L.S.; Mao, B.W.; Yuan, Y.Z.; Huang, R.B.; Zheng, L.S. Nanoporous Lanthanide-Copper(II) Coordination Polymers: Syntheses and Crystal Structures of $\left[\left\{\mathrm{M}_{2}\left(\mathrm{Cu}_{3}(\text { iminodiacetate })_{6}\right)\right\} \cdot 8 \mathrm{H}_{2} \mathrm{O}\right] \mathrm{n}(\mathrm{M}=\mathrm{La}$, Nd, Eu). Angew. Chem. Int. Ed. 2003, 42, 532-535. [CrossRef]

11. Zhou, Y.F.; Jiang, F.L.; Yuan, D.Q.; Wu, B.L.; Wang, R.H.; Lin, Z.Z.; Hong, M.C. Copper Complex Cation Templated Gadolinium(III)-Isophthalate Frameworks. Angew. Chem. Int. Ed. 2004, 43, 5665-5668. [CrossRef] [PubMed]

12. Zhao, X.Q.; Zhao, B.; Wei, S.; Cheng, P. Synthesis, Structures, and Luminescent and Magnetic Properties. Inorg. Chem. 2009, 48, 11048-11057. [CrossRef] [PubMed]

13. Tian, C.B.; Yuan, D.Q.; Han, Y.H.; Li, Z.H.; Lin, P.; Du, S.W. Synthesis, structures, and magnetic properties of a series of new heterometallic hexanuclear Co2Ln4 $(\mathrm{Ln}=\mathrm{Eu}, \mathrm{Gd}, \mathrm{Tb}$ and $\mathrm{Dy})$ clusters. Inorg. Chem. Front. 2014, 1, 695-704. [CrossRef]

14. Du, P.W.; Schneider, J.; Luo, G.G.; Brennessel, W.W.; Eisenberg, R. Visible Light-Driven Hydrogen Production from Aqueous Protons Catalyzed by Molecular Cobaloxime Catalysts. Inorg. Chem. 2009, 48, 4952-4962. [CrossRef] [PubMed]

15. Piquer, L.R.; Sañudo, E.C. Heterometallic 3d-4f single-molecule magnets. Dalton Trans. 2015, 44, 8771-8780. [CrossRef] [PubMed] 
16. Wang, H.S.; Yang, F.J.; Long, Q.Q.; Huang, Z.Y.; Chen, W.; Pan, Z.Q. Syntheses, crystal structures, and magnetic properties of a family of heterometallic octanuclear [Cu6Ln2] (Ln = Dy(III), Tb(III), Ho(III), Er(III), and Gd(III)) complexes. New J. Chem. 2017, 41, 5884-5892. [CrossRef]

17. Yamaguchi, T.; Sunatsuki, Y.; Kojima, M.; Akashi, H.; Tsuchimoto, M.; Re, N.; Osae, S.; Matsumotoe, N. Ferromagnetic NiII-GdIII interactions in complexes with NiGd, NiGdNi, and NiGdGdNi cores supported by tripodal ligands. Chem. Commun. 2004, 9, 1048-1049. [CrossRef]

18. Singha, S.K.; Rajaraman, G. Decisive interactions that determine ferro/antiferromagnetic coupling in $\{3 \mathrm{~d}-4 \mathrm{f}\}$ pairs: A case study on dinuclear $\{$ V(IV)-Gd(III) $\}$ complexes. Dalton Trans. 2013, 42, 3623-3630. [CrossRef]

19. Manna, S.C.; Konar, S.; Zangrando, E.; Ribas, J.; Chaudhuri, N.R. 3D Heterometallic (3d-4f) coordination polymers: A ferromagnetic interaction in a Gd(III)-Cu(II) couple. Polyhedron 2007, 26, 2507-2516. [CrossRef]

20. Goura, J.; Chakraborty, A.; Walsh, J.P.S.; Tuna, F.; Chandrasekhar, V. Hexanuclear 3d-4f Neutral CoII $2 \mathrm{LnIII}_{4}$ Clusters: Synthesis, Structure, and Magnetism. Cryst. Growth Des. 2015, 15, 3157-3165. [CrossRef]

21. Bruker AXS. SAINT Software Reference Manual; Bruker: Madison, WI, USA, 1998.

22. Sheldrick, G.M. SHELXT-Integrated space-group and crystal-structure determination. Acta Cryst. 2015, 71, 3-8. [CrossRef]

23. Yeh, C.Y.; Chiang, Y.L.; Lee, G.H.; Peng, S.M. Unsymmetrical Linear Pentanuclear Nickel String Complexes: $\left[\mathrm{Ni}_{5}(\mathrm{tpda})_{4}\left(\mathrm{H}_{2} \mathrm{O}\right)\left(\mathrm{BF}_{4}\right)\right]\left(\mathrm{BF}_{4}\right)_{2}$ and $\left[\mathrm{Ni}_{5}(\mathrm{tpda})_{4}\left(\mathrm{SO}_{3} \mathrm{CF}_{3}\right)_{2}\right]\left(\mathrm{SO}_{3} \mathrm{CF}_{3}\right)$. Inorg. Chem. 2002, 41, 4096-4098. [CrossRef]

24. Chakraborty, A.; Ghosh, B.K.; Ribas-Arino, J.; Ribas, J.; Maji, T.K. A Heterometallic (Ni-II-Cu-II) Decanuclear Cluster Containing Two Distorted Cubane-like Pentanuclear Cores: Synthesis, Structure, and Magnetic Properties. Inorg. Chem. 2012, 51, 6440-6442. [CrossRef] [PubMed]

25. Ikeda, K.; Ohba, M.; Ōkawa, H. Dinuclear CuII and NiII complexes of 3-formylsalicylic acid oxime: Cis/trans topology and extension of a cis-CuII 2 complex to a pentanuclear CuIICuIIMnIICuIICuII complex. J. Chem. Soc. Dalton Trans. 2001, 20, 3119-3124. [CrossRef]

26. Wang, B.C.; Chen, X.L.; Hu, H.M.; Yao, H.L.; Xue, G.L. Two novel Zn(II) coordination polymers based on trigonal ligand: 40-(4-pyridyl)-3,20:60,300-terpyridine. Inorg. Chem. Commun. 2009, 12, 856-859. [CrossRef]

27. Modak, R.; Sikdar, Y.; Cosquer, G.; Chatterjee, S.; Yamashita, M.; Goswami, S. Heterometallic CuII-DyIII Clusters of Different Nuclearities with Slow Magnetic Relaxation. Inorg. Chem. 2016, 55, 691-699. [CrossRef] [PubMed]

28. Li, H.; Shi, W.; Niu, Z.; Zhou, J.M.; Xiong, G.; Li, L.L.; Cheng, P. Remarkable LnIII3FeIII2 clusters with magnetocaloric effect and slow magnetic relaxation. Dalton Trans. 2015, 44, 468-470. [CrossRef] [PubMed]

29. Li, C.; Li, H.D.; Xie, J.; Yang, M.; Wang, X.F.; Li, L.C. $\left\{\left[\mathrm{Ln}(\mathrm{hfac})_{3}\right]_{2}\left[\mathrm{Cu}(\mathrm{hfac})_{2}\right]_{3}(\mathrm{NIT}-\mathrm{Pyrim})_{2}\left(\mathrm{H}_{2} \mathrm{O}\right)_{2}\right\}(\mathrm{LnIII}=$ Gd, Ho, Er): Unique nitronyl nitroxide-bridged 3d-4f heterometallic clusters. Eur. J. Inorg. Chem. 2018, 31, 525-530. [CrossRef]

30. Wang, X.Q.; Li, Z.Y.; Zhu, Z.X.; Zhu, J.; Liu, S.Q.; Ni, J.; Zhang, J.J. Pentanuclear $\{\mathrm{Cr}(2) \operatorname{Ln}(3)\}(\operatorname{Ln}=\mathrm{Dy}, \mathrm{Tb})$ Heterometallic Clusters Based on an Amino Acid Ligand: Slow Relaxation of Magnetization and Substitution Reactions. Eur. J. Inorg. Chem. 2013, 2013, 5153-5160. [CrossRef]

31. Zhu, Q.L.; Xiang, S.C.; Sheng, T.L.; Yuan, D.Q.; Shen, C.J.; Tan, C.H.; Hu, S.M.; Wu, X.T. A series of goblet-like heterometallic pentanuclear $[\mathrm{Ln}(\mathrm{III}) \mathrm{Cu}(4)(\mathrm{II})]$ clusters featuring ferromagnetic coupling and single-molecule magnet behavior. Chem. Commun. 2012, 48, 10736-10738. [CrossRef]

32. Saha, S.; Sarkar, A.; Das, S.; Panda, T.K.; Harms, K.; Nayek, H.P. The Missing Link in Ni(II)-Ln(III) System: Design and Synthesis of a Dinuclear $\left[\mathrm{Ni}_{2}\right]$ and Three Pentanuclear $\left[\mathrm{Ni}_{3} \mathrm{Ln}_{2}\right](\mathrm{Ln}=\mathrm{La}, \mathrm{Ce}, \mathrm{Eu})$ Complexes of a Schiff Base Ligand. ChemistrySelect 2017, 2, 7865-7872. [CrossRef]

33. Bag, P.; Chakraborty, A.; Rogez, G.; Chandrasekhar, V. Pentanuclear Heteronnetallic $\{\operatorname{Mn}(2)(\operatorname{III}) \operatorname{Ln}(3)\}(\operatorname{Ln}=$ Gd, Dy, Tb, Ho) Assemblies in an Open-Book Type Structural Topology: Appearance of Slow Relaxation of Magnetization in the Dy(III) and Ho(III) Analogues. Inorg. Chem. 2014, 53, 6524-6533. [CrossRef] [PubMed]

34. Ke, H.S.; Zhao, L.; Guo, Y.; Tang, J.K. Polydentate-ligand-supported self-assembly of heterometallic T-shaped Co4RE $(\mathrm{RE}=\mathrm{Gd}, \mathrm{Tb}, \mathrm{Y})$ clusters: Synthesis, structure and magnetism. Dalton Trans. 2012, 41, 9760-9765. [CrossRef] [PubMed]

35. Liu, P.P.; Wang, C.Y.; Zhang, M.; Song, X.Q. Pentanuclear Sandwich-type ZnII-LnIII clusters based on a new Salen-like salicylamide ligand: Structure, near-infraed emission and magnetic properties. Polyhedron 2017, 129, 133-140. [CrossRef] 
36. Voronkova, V.K.; Galeev, R.T.; Shova, S.; Novitchi, G.; Turta, C.I.; Caneschi, A.; Gatteschi, D.; Lipkowski, J.; Simonov, Y.A. Exchange Interaction and Spin Dynamics in Pentanuclear Clusters, $\mathrm{Cu}_{3} \mathrm{Ln}_{2}\left(\mathrm{CICH}_{2} \mathrm{COO}\right)_{12}\left(\mathrm{H}_{2} \mathrm{O}\right)\left(\mathrm{Ln}=\mathrm{Nd}^{3+}, \mathrm{Sm}^{3+}, \mathrm{Pr}^{3+}\right)$. Appl. Magn. Reson. 2003, 25, 227-247. [CrossRef]

37. Zhao, X.Q.; Liu, X.H.; Kang, X.M.; Zhao, B. Self-Assembly of Heterometallic LnIII-CoII Coordination Polymers: Syntheses, Structures, and Magnetic Studies. Dalton Trans. 2015, 44, 18856-18863. [CrossRef]

38. Gómez, V.; Vendier, L.; Corbella, M.; Costes, J.P. Tetranuclear [Co-Gd $]_{2}$ Complexes: Aiming at a Better Understanding of the 3d-Gd Magnetic Interaction. Inorg. Chem. 2012, 51, 6396-6404. [CrossRef]

39. Li, Z.Y.; Dai, Y.; Zhang, H.; Zhu, J.; Zhang, J.J.; Liu, S.Q.; Duan, C.Y. Square and Butterfly Tetranuclear [Co2Ln2] Clusters Built from the Same Building Blocks but Displaying Different Magnetic Properties: Structural Variation by Means of Solvent and the Radii of $\mathrm{Ln}^{3+}$ Ions. Eur. J. Inorg. Chem. 2014, 2014, 384-391. [CrossRef]

40. Costes, J.P.; Vendiera, L.; Wernsdorferc, W. Structural and magnetic studies of original tetranuclear CoII-LnIII complexes $(\mathrm{LnIII}=\mathrm{Gd}, \mathrm{Tb}, \mathrm{Y})$. Dalton Trans. 2011, 40, 1700-1706. [CrossRef]

41. Li, C.J.; Lin, Z.J.; Peng, M.X.; Leng, J.D.; Yang, M.M.; Tong, M.L. Novel three-dimensional 3d-4f microporous magnets exhibiting selective gas adsorption behavior. Chem. Commun. 2008, 47, 6348-6350. [CrossRef]

42. Zhu, Y.; Luo, F.; Feng, X.F.; Liao, Z.W.; Song, Y.M.; Huang, H.X.; Tian, X.Z.; Sun, G.M.; Luo, M.B. Simple Method and Materials to Target Co(II)-Dy(III) Multi-Nuclear Magnetic Compounds and Single Molecule Magnets (SMMs): Synthesis, Structure, and Magnetic Studies. Aust. J. Chem. 2013, 66, 75-83. [CrossRef]

43. Gao, H.L.; Zhao, B.; Zhao, X.Q.; Song, Y.; Cheng, P.; Liao, D.Z.; Yan, S.P. Structures and Magnetic Properties of Ferromagnetic Coupling 2D Ln-M Heterometallic Coordination Polymers (Ln) Ho, Er; M) Mn, Zn). Inorg. Chem. 2008, 47, 11057-11061. [CrossRef]

(C) 2019 by the authors. Licensee MDPI, Basel, Switzerland. This article is an open access article distributed under the terms and conditions of the Creative Commons Attribution (CC BY) license (http:/ / creativecommons.org/licenses/by/4.0/). 